\title{
Local Environmental Non-Profit Organizations and the Green Investment Strategies of Family Firms
}

\author{
Daniela Maggioni $^{\mathrm{a}, *}$, Grazia D. Santangelo ${ }^{\mathrm{b}}$ \\ ${ }^{a}$ Ca' Foscari University of Venice, Department of Economics, Cannaregio 873, 30121 Venice, Italy \\ ${ }^{\mathrm{b}}$ University of Catania, Department of Political and Social Science, Via V. Emanuele II, 8, Catania 95131, Italy
}

\section{A R T I C L E I N F O}

\section{Article history:}

Received 17 July 2016

Received in revised form 18 December 2016

Accepted 16 March 2017

Available online $\mathrm{xxxx}$

JEL classification:
Q52
Q56
R11
C25

Keywords:

ENPOs

GIS

Sectoral regulation

Family firms

\begin{abstract}
A B S T R A C T
We add to the debate on the determinants of firms' green investment strategies (GIS) by looking at societal stakeholders and explicitly testing the role of local environmental non-profit organizations (ENPOs) in GIS engagement by family and non-family firms. We argue that ENPOs favor GIS engagement only by family firms, which, due to their resource constraints, risk aversion and local embeddedness, are more sensitive to ENPOs normative pressure. We also suggest that the role of ENPOs is especially important for family firms' GIS in those sectors with less stringent regulations, where ENPOs may act as a substitute for the coercive pressure of regulation, and promote firms' self-regulatory behaviors. We test and find support for our arguments on a sample of about 2000 Italian manufacturing firms over the period 2001-2003. Our results are robust to the control of observable omitted variables, reverse causality and to alternative model specifications.
\end{abstract}

(c) 2017 Elsevier B.V. All rights reserved.

\section{Introduction}

European Union (EU) members are increasingly under scrutiny to achieve a sustainable growth path. The raising of environmental concerns at the EU level is reflected in the proliferation of regulations and actions by the Union over the last decade. The launch of the EU Resource Efficiency Roadmap in 2001, the creation of the Emissions Trading System to monitor $\mathrm{CO}_{2}$ emissions in 2005, and the emphasis on the achievement of a sustainable pattern of economic growth in the Horizon 2020 program are some of the initiatives documenting the EU pressure on member states to promote a green-friendly growth.

In addition to the coercive pressure of the EU and national environmental regulators, private firms are also exposed to the normative pressure of other secondary stakeholders, which increasingly

\footnotetext{
* Corresponding author.

E-mail addresses: daniela.maggioni@unive.it (D. Maggioni), grsanta@unict.it (G.D. Santangelo).
}

call for an environmental sustainable behavior of economic agents. These stakeholders are societal stakeholders, and mobilize public opinion in favor or in opposition to firm's decisions and operations that may have an environmental impact (Clarkson, 1995; Etzion, 2007).

The emergence of societal stakeholders is a relatively recent phenomenon and a source of diverse external pressures to the firm (Doh and Guay, 2004; Etzion, 2007; Mitchell et al., 1997) because these stakeholders, unlike primary stakeholders (i.e. management and non-management employees, consumers and suppliers), do not have a formal contractual bond with the firm (Freeman, 2004; Henriques and Sadorsky, 1996; Mitchell et al., 1997).

Among societal stakeholders, the emergence of environmental non-profit organizations (ENPOs) dates back to a couple of decades and strictly connects to the growing awareness of environmental issues in civil society (Doh and Guay, 2004). Because firms are not contractually or legally obliged to ENPOs, these societal stakeholders generally utilize indirect approaches (e.g. public protests, civil suits and letter writing campaigns) to influence firms environmental strategy (Eesley and Lenox, 2006; Sharma and Henriques, 2005). 
Still, the action of ENPOs may substantially harm firms' reputation and competitiveness (Eesley and Lenox, 2006), and ENPOs normative pressure may both reinforce the coercive pressure of regulations and compensate for the lack of it.

Yet, despite the recently recognized relevance of different external environmental pressures on green management practices (Appolloni et al., 2014; Zhu et al., 2016), the environmental economic literature, has overlooked the role of non-profit organizations (NPOs) as distinctive societal stakeholders. The few aggregate analyses, which have investigated the role of local societal stakeholders as a relevant force driving firms' environmental behavior, have either focused on local communities, or bundled ENPOs together with other societal stakeholders (Aden et al., 1999; Bernauer et al., 2013; Cribb, 1990; Epstein and Schnietz, 2002; Fredriksson et al., 2005; Neumayer and Perkins, 2004; Triguero et al., 2013). The distinctive role of ENPOs gains great relevance in connection to different organizational forms and to family firms especially, because these are the dominant organizational form around the world (Gersick et al., 1997; Porta et al., 1999) and have been found to be more responsive to local societal pressure (Berrone et al., 2010; Gómez-Mejía et al., 2007).

A rigorous research on the role ENPOs play in influencing firms green behavior is still missing. We aim at filling this gap by investigating the influence of ENPOs operating in the firms' local context on the engagement in green investments strategies (GIS) (i.e., investments in environmentally oriented equipments) by family and nonfamily firms. Based on stakeholder theory (Eesley and Lenox, 2006; Freeman, 2004; Guay et al., 2004; Mitchell et al., 1997) and organization science (Berrone et al., 2010; Gómez-Mejía et al., 2007), we suggest that family firms are more responsive to ENPOs pressure than non-family firms and, hence, more likely to engage in GIS because their resource constraints make them less capable to bear the costs of head-to-head confrontation with ENPOs (Gomez-Mejia et al., 2003; Hamelin, 2013; Zellweger and Sieger, 2012), and, at the same time, they need to build a positive reputation that "may serve as a form of social insurance protecting the firm's assets in times of crisis" (dye, 2006). In addition, we investigate how local ENPOs interact with sectoral regulations by disclosing the existence of a substitutability linkage in prompting family firms' GIS engagement.

We test our arguments in the manufacturing sector in Italy, which represents a suitable research setting. According to Eurostat, Italy ranks among the developed countries recording the highest percentage of environmental expenditures of the manufacturing sector. Italy also displays a high geographical heterogeneity in terms of environmental performance, and number of local ENPOs (such as Italia Nostra, Legambiente and Verdi Ambiente e Societa'). Finally, in the country family firms account for a large share in the economy (Corbetta and Montemerlo, 1999), which European Family Businesses estimates about $75 \%$ of all active firms in Italy. ${ }^{1}$

The work is structured as follows. The next section reviews the background literature and develops testable hypotheses. Section 3 discusses data and empirical strategy. Section 4 illustrates the results. Finally, conclusions are discussed in Section 5.

\section{Background Literature and Hypotheses}

Our research connects to the increasing effort of the environmental economics literature to disclose the drivers of firms' environmental behavior. To this end, we focus on GIS and draw on stakeholder theory and organization science to explore the differential role of

\footnotetext{
1 http://www.europeanfamilybusinesses.eu/
}

local ENPOs in shaping environmental responsible behavior of family and non-family firms.

In relation to primary stakeholders, a number of studies have explored customers' pressure, demand, satisfaction and benefits as a driver of firms' environmental behavior (Horbach et al., 2012; Kammerer, 2009; Rehfeld et al., 2007). The relevance of societal stakeholders has been studied both at macro and micro level.

At macro level, extant research suggests that the demand from civil society, either direct or channeled by non-governmental organizations (a specific type of NPOs), can foster countries' environmental performance (Bernauer et al., 2013; Fredriksson et al., 2005; Neumayer and Perkins, 2004). Environmental NGOs can exert pressure both on governments by promoting the ratification, enforcement and compliance of international treaties and national regulations.

In connection to firms' adoption of cleaner production technologies and behavior, the role of ENPOs has been investigated primarily by means of case studies, which have shown that environmental activists can impose losses to polluting firms (Cribb, 1990; Epstein and Schnietz, 2002). A few quantitative firm-level studies have focused on local communities and societal stakeholders (Aden et al., 1999; Becker, 2003; Mazzanti and Zoboli, 2009), but typically bundled these different actors altogether. In sum, work in environmental economics seems to have so far overlooked the distinctive role of ENPOs, although the salience of this societal stakeholder has increased drastically in the last couple of decades (Doh and Guay, 2004).

A widespread local presence of ENPOs can influence firm's GIS through different channels. First, firms may be encouraged to engage in GIS by the desire to avoid costs related to civil suits initiated by the local ENPOs as well as the protests local ENPOs may organize to physically stop firm's activities (Argenti, 2004). Second, firm's GIS may be motivated by the will to avoid negative media exposure and reputation damages resulting from the activities of local ENPOs (Deephouse and Carter, 2005). In addition, the presence of ENPOs may reflect locally shared beliefs and values (Binder and Blankenberg, 2016), which management and non-management employees, who have been raised and/or live in the local context, can bring in the firm, thus exerting a direct impact on the firm environmental strategy (Doh and Guay, 2006). At the same time, local ENPOs may favor the emergence of locally shared beliefs and values by increasing other stakeholders' (e.g. consumers) awareness on environmental issues (Sharma and Henriques, 2005).

Yet, firms are heterogeneous in the way they respond to normative pressures (Murillo-Luna et al., 2008). The influence of ENPOs on firms' GIS may then critically depend on the firm's organizational form. In particular, we expect a stronger impact of ENPOs on family firms because these firms are more resource-constrained and, at the same time, more dependent on the local context than non-family firms. Due to their typical smaller size, family firms suffer from capital constraints and, hence, are reluctant to adopt riskier behavior and aggressive competition strategies than non-family firms (Gomez-Mejia et al., 2003; Hamelin, 2013; Zellweger and Sieger, 2012). Relatively limited resources may deter also family firms from head-to-head confrontation with local ENPOs in order to avoid costs related to ENPOs protests, which may stop or delay production, legal costs associated to civil suits initiated by ENPOs, and the costs related to fines resulting from ENPOs denounces. While large businesses would eventually have the resources to face such costs, family firms may prefer to compel with ENPOs normative pressure and proactively engage in GIS, valuing GIS engagement less costly than the costs of fighting against ENPOs. Furthermore, GIS engagement can yield reputational benefits in the local context where the firm is traditionally embedded. These benefits are especially relevant for family than non-family firms because, in virtue of their greater local embeddedness (Graafland, 2002), family businesses are more dependent on the local context for their survival than their nonfamily counterparts (Clarkson, 1995) and, hence, they strive to gain 
local legitimacy by building trustworthy relationships with stakeholders (Cennamo et al., 2009; Jones and Wicks, 1999; Laplume et al., 2008). They are committed to project and perpetuate a positive family image and reputation (Westhead et al., 2001). Family firms also strive to receive recognition for generous actions (Schulze et al., 2001), to enjoy personal prestige in the community and to have social support among friends and acquaintances (Stafford et al., 1999), as well as to maintain group integrity (Habbershon and Pistrui, 2002). Hence, they value "social worthiness", that is the legitimacy derived from conformity to local expectations (Thornton and Ocasio, 1999). As a result, family firms are more sensitive to socioemotional rewards, and they also regard, in addition to economic outcomes, non-economic utilities such as "socio-emotional wealth" or "affective endowments" as a means to preserve and nurture their local embeddedness (Gómez-Mejía et al., 2007), and are eventually more environmentally responsible (Berrone et al., 2010). We then expect family firms to be more responsive to the normative pressures stemming from the local context where they operate and, in particular, to the requests of the local communities channeled by local ENPOs. Hence, we posit:

Hypothesis 1. The larger the presence of local ENPOs, the greater the likelihood of GIS engagement by family than non-family firms.

The influence of ENPOs on family firms' GIS engagement, however, may vary across sectors depending on the sectoral stringency of environmental regulations. Given the direct impact that firms' production activities and their environmental performance can have on the local area where they operate, local ENPOs exert a normative pressure for environmental friendly behavior (Eesley and Lenox, 2006) substituting for the coercive pressure exerted by regulators (Mitchell et al., 1997). This argument mirrors Bernauer et al. (2013). They find that environmental NGOs, play an important role in countries' participation to international environmental agreements, but their importance decreases with the democracy level of the country. Environmental NGOs, indeed, would compensate for the lack of a large number of political forces and demand channels, which characterize democratic countries. A similar mechanism can apply in our context.

Absent regulations or lax regulatory enforcement typically lower production costs, and favor firm polluting investments and local environmental degradation (Madsen, 2009). Local ENPOs may exert a higher pressure in those sectors where no strict regulation obliges firms to invest in environment due to either a lower pollution intensity or a weaker attention by policy-makers. Hence, in these sectors firms' environmental performance mostly depends on selfregulatory strategies. In particular, ENPOs can push local firms to adapt new environmental standards and ease innovation (as in the weaker version of the Porter Hypothesis), and eventually firms' competitiveness (as in the stronger version of the Porter Hypothesis) (Porter, 1991; Porter and van der Linde, 1995). In both cases, the ENPOs action may be assimilated to market-based environmental policies, which, unlike traditional command-and-control regulatory programs, provide greater flexibility to internalize pollution and may be especially appropriate in connection to resource-constrained firms such as family businesses. We then expect that local ENPOs spur firms' GIS comparatively more in those sectors where family firms are exposed to a lower level of environmental stringency. Thus, we suggest:

Hypothesis 2. A large presence of local ENPOs substitutes for the strength of sectoral environmental regulations on the likelihood of a family firm engaging in GIS.

\section{Data and Empirical Framework}

\subsection{Data}

For our empirical analysis, we rely on the 9th wave of the Capitalia (formerly Mediocredito Centrale) survey, which provides crosssectional information on Italian manufacturing firms' characteristics and their activities for the year 2003 and a number of time-varying information for the period 2001-2003. The dataset covers all firms with more than 500 employees and a sample of firms with more than 10 and less than 500 employees, which are selected stratifying by sector, size class and geographical area.

Drawing on a large literature on family business and the EU definition (Chrisman et al., 2012; Commission, 2009; Miller et al., 2011; Villalonga and Amit, 2006; Yoshikawa and Rasheed, 2010; Zahra, 2010), we define family firms based on both family involvement in the firm ownership and the presence of family managers in the firm board. Then, resting on the information available in the Capitalia survey, we operationalize this definition as those firms whose main shareholder is a physical individual, and whose entrepreneurs and executives belonging to the family account for a share greater than $50 \%$ in the firm board. Also, to unambiguously identify family business, we exclude from our family firm definition those firms belonging to a group, firms listed on the stock exchange and foreignowned firms because in all these cases the role of the family may be limited. ${ }^{2}$ Foreign-owned firms are identified as those controlled by foreign shareholders owing at least $10 \%$ of the firm's capital share. ${ }^{3}$

The Capitalia dataset, which has been used in previous studies (e.g. Antonietti and Marzucchi (2014)), serves our research purposes to explore the impact of ENPOs on firms' activities. In the early 2000s, ENPOs were still an emerging phenomenon and firms' green actions were mainly implemented on a voluntary basis due to less strict regulations and the lower green awareness spread in civil society at the time. Over the 2000s the increase in environmental stringency ${ }^{4}$ has gone hand in hand with a raise in green consciousness of civil society and a stronger normative pressure by ENPOs for green investments by firms. Yet, the enforcement of regulations remains still far from being ideal. ${ }^{5}$ Thus, we believe that our analysis is not confined to the period and country we analyze, and they may also offer insights in countries with low compliance of environmental regulations.

To test the role of ENPOs on firms' GIS engagement, we combine the Capitalia survey with a number of territorial-level variables, which we gather from different data sources as discussed below. We consider territorial units at the NUTS3-level, ${ }^{6}$ which for Italy correspond to 103 administrative provinces in the period of our analysis.

\footnotetext{
2 In alternative specifications we test the robustness of our baseline models to different family firms definitions, and find support for our findings. Results are not reported and available upon request.

3 The lack of information on the presence of entrepreneurs and executives resulted in a loss of observations.

4 In the last two decades, Italy has implemented a number of initiatives at national level (e.g., a new waste system based on a full-cost pricing tariff introduced in 1997 and implemented during the 2000s; a new Environmental Code in force since 2006; a new legislation on environmental crimes issued in 2015) and actively participated in initiatives at the European level (e.g., the 2001 EU Resource Efficiency Roadmap; the Emission Trade System creation in 2005; the Horizon 2020 program) to safeguard the environment and reduce pollutants' emissions.

5 According to the 2015 "Travel \& Tourism Competitiveness Report" of the World Economic Forum, Italy ranks $49^{\text {th }}\left(84^{\text {th }}\right)$ over 141 countries in terms of stringency of environmental regulations (enforcement of environmental regulations) as perceived in the Executive Opinion Survey administered by the Forum.

6 NUTS stands for the Nomenclature of Territorial Units of Statistics developed by Eurostat.
} 


\subsection{Dependent Variable}

In the Capitalia survey firms are requested to declare the importance of the reduction of the environmental impact of their activity as motivation driving their decisions to undertake tangible investments during the period 2001-2003. Firms have the possibility to choose among three values: low, medium and high. We create a dummy $\left(\right.$ Green $\left.^{I n v}\right)$ taking value 1 if the firm rates the motivation of "environmental impact reduction" as "high" or "medium", 0 if it rates it as "low". The decision to use a binary variable instead of focusing on an ordinal variable rests on the kind of information collected by the survey. While the environmental impact is a cogent concern for firms active in pollution-intensive sectors, other motivations can take priority for firms active in sectors characterized by lower pollution intensity. Firms in less polluted sectors could value less their environmental sustainability than other goals. Hence, our binary measure is more likely to reflect the firm's green attitude rather than the sectoral distribution of our sample firms. The use of the binary variable represents also a reasonable alternative to environmental expenditures and investments, which are not available in the survey, because our indicator can still capture the effort of the firm to internalize the economy-wide environmental costs resulting from the firms activities. The same strategy has been adopted by Cainelli et al. (2015) and similar proxies for green investments and innovations have been used in other studies (De Marchi, 2012; Horbach, 2008). We, however, test the robustness of our baseline findings to the use of an ordinal dependent variable as well as a proxy for the amount of green investments.

According to our data, firms investing in the reduction of harmful environmental impact account for $52.6 \%$ of investors and $45 \%$ of the total sample, a figure that is in line with the existing evidence in terms of share of eco-innovators (Cainelli et al., 2015; Horbach et al., 2012). When focusing on firms' ownership, we find that family firms, accounting for nearly $42 \%$ of the sample, present a lower probability to engage in GIS than non-family firms (48.4\% versus $55.6 \%)$

Panels A and B in Fig. 1 show the geographical distribution of firms engaging in GIS across Italian provinces for both family and non-family firms. We disclose the existence of a substantial heterogeneity in firms' green attitude over the geographical space. Also, territorial differences in the GIS engagement emerge between family and non-family firms, thus suggesting the existence of different underlying determinants for the two groups of firms.

\subsection{Independent Variables}

In order to test Hypothesis 1, we retrieve information on the number of NPOs engaged in the protection, defense and promotion of environment at province level from the 1999 Istat (Italian National Institute of Statistics) Census on non-profit organizations. ${ }^{7}$ To account for the size of the province, we normalize this indicator by the provincial population (source: Istat). Our main independent variable is, thus, represented by the logarithm of the number of ENPOs per capita (per million of inhabitants) in 1999 (ENPO_p $\left.c_{p}\right)$.

Panel $C$ in Fig. 1 shows the distribution of ENPO_p $c_{p}$ across Italian provinces. Nuoro, Belluno and Gorizia present a larger number of ENPOs, while Ragusa, Agrigento and Taranto are located in the lower tail of the variable distribution. While the Figure in part reflects the

\footnotetext{
7 We exclude those NPOs whose main activity consists of the protection of animals, which is not directly related to the promotion and protection of environmental quality. Our results are however robust to the inclusion of these associations in the definition of the independent variable. These estimations are not reported and available upon request.
}

North-South economic divide, which characterizes Italy, it is worth highlighting that some Northern provinces (e.g., Rimini and Venezia) are in the lowest quartile of the distribution, and some Southern and Central provinces (e.g. Cagliari and L'Aquila) are in the top quartile of the distribution. There appears then to exist enough variation across provinces to identify the role of local ENPOs in prompting firms' GIS. Comparing this distribution with the diffusion of GIS engagement among family and non-family firms (Panels A and B), it emerges a higher correlation between the diffusion of ENPOs and the distribution of GIS engagement among family firms than non-family firms.

To test Hypothesis 2, we exploit data on environmental taxes at 2-digit NACE sector level in 1999 from Eurostat, which are normalized by sectoral value added (env_string). This indicator represents a proxy for the stringency of existing environmental regulations and their enforcement. We also exploit information on emissions (Brunel and Levinson, 2013) to capture environmental regulatory stringency. We consider higher levels of emission per unit of value added as reflecting the presence of stringent regulations in the sector because policy makers will devote more effort to regulate most polluting activities. This is confirmed for example by the current EU Emission Trade System in force in the EU since 2005, which regulates the carbon dioxide emissions only for energy intensive sectors. Resting on NAMEA data, we both use information on sectoral carbon dioxide $\left(\mathrm{CO}_{2}\right)$ emissions, and we build an indicator of Global Warming Potential (GWP) and acidification. ${ }^{8}$

In our model, to account for local community pressure other than ENPOs we also control for the presence of NPOs pursuing goals different than the protection and defense of environment (non $E N P O s \_p c_{p}$ ) (e.g. labor unions).

In addition, following the existing literature (Horbach et al., 2012) we account for market pull drivers, technology push, firm specific factors and policy measures. As for the market pull drivers, we control for the firm's share of sales in the provincial market (mkt_prov). We then add a dummy for firms that measure customer satisfaction (satisfaction) and a dummy for firms with ISO9000 quality certification (quality_cert). All these measures are retrieved from the Capitalia survey. Among technology push factors and firm internal resources, we test for the education level of workforce measured with the share of employees with secondary and tertiary education (education), and with three dummies denoting firm's engagement in R\&D activity (rd_status), the affiliation to a group (group), and the purchase of patents from abroad (patent $^{\text {For }}$ ), respectively. Also, we include further firm-level variables from Capitalia which can reflect the pool of knowledge and capabilities firms can exploit, and in particular, firm's age (age), firm size proxied by the number of employees (size), and capital intensity $(\mathrm{kl})$ proxied by the book value of tangible assets over the number of employees. Concerning policy measures, we include the NUTS3-level share of sorted waste collection (waste ${ }_{p}^{\text {sorted }}$ ) (source: Istat), which could capture different local regulations in force and a different attitude of local policy makers towards environmental issues. We then control for further province-level indicators capturing the local economic conditions in 1999, which are the provincial value-added per capita $\left(v a_{-} p c_{p}\right)$ (source: Istituto Tagliacarne), and the employment share (emp_sh $h_{p}$ ) (source: Istat).

After dropping those firms presenting missing or inconsistent values for the dependent variable and covariates we use in the analysis, we end up with a sample of 2744 firms. 2338 of these declare

\footnotetext{
8 Based on Eurostat, the GWP indicator is computed as $\mathrm{CO}^{2}+298 * \mathrm{~N}^{2} \mathrm{O}+25 * \mathrm{CH}^{4}$, and the acidification indicator as SOX $+0.7 * N O X+1.9 * N H^{3}$ (http://ec.europa.eu/ eurostat/statistics-explained/index.php/Greenhouse_gas_emission_statistics).
} 
A

$\%$ Family firms undertaking GIS

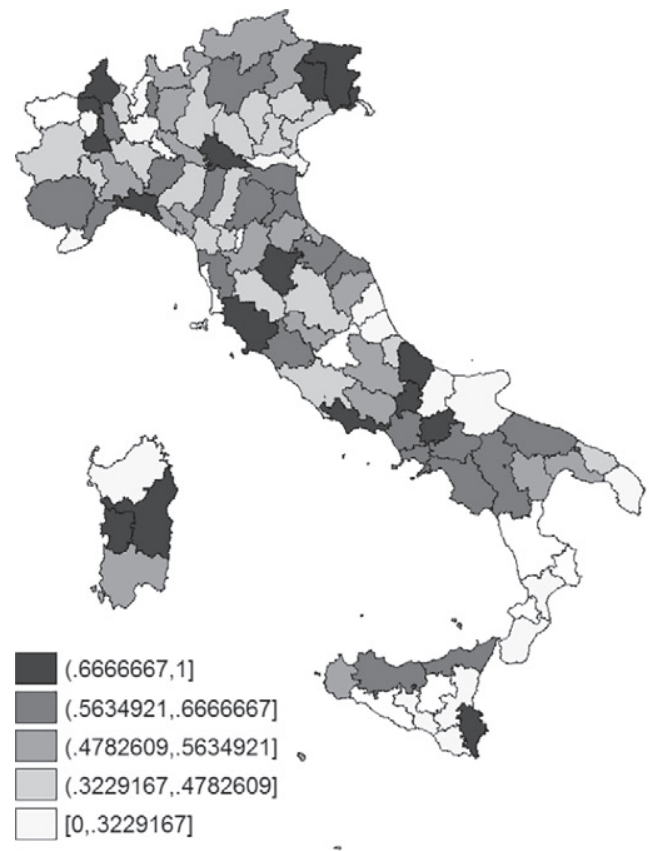

B

$\%$ Non-family firms undertaking GIS

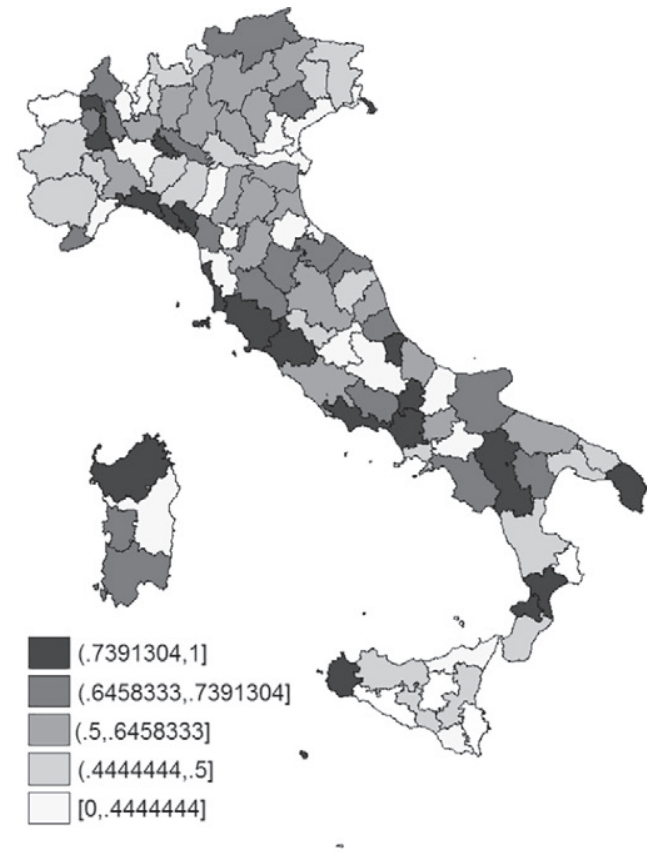

C

ENPOs per capita, 1999

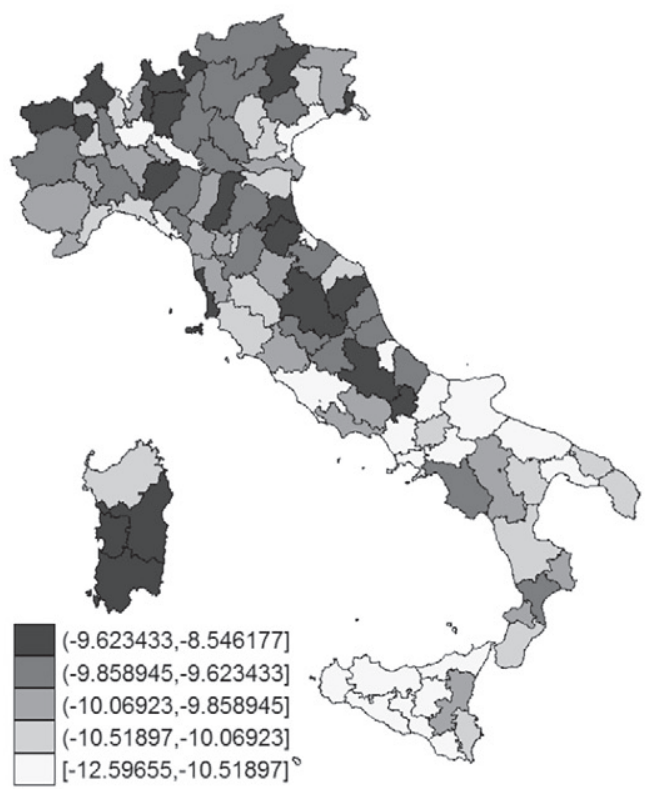

Fig. 1. Numberof ENPOs per capita and firms' GIS diffusion across Italian provinces.

quintiles of the distributions of ENPOs and firms' GIS engagement are represented by means of different grey tonalities, with the darker ones identifying upper quintiles. Source: Istat and Capitalia Survey. Authors' calculations.

to undertake investments in tangible assets. The latter group of firms represent the sample we use in our empirical strategy, which counts 986 family firms and 1289 non-family firms. The focus on investors may yield a mild sample selection bias that may affect our estimates. We therefore address such a bias in our estimation strategy.

Descriptive statistics and correlation matrix are reported in Table A1 in the Appendix. 


\subsection{Estimation Strategy}

Due to the binary nature of the dependent variable, we estimate the following cross-sectional probit model: ${ }^{9}$

$\operatorname{Pr}\left(\right.$ Green $\left._{i p s}^{I n v}=1\right)=\Phi\left(\alpha+\beta E N P O \_c_{p}+\delta X_{i}+\phi Z_{p}+\gamma_{r}+\eta_{s}\right)$

where, Green ${ }_{i p s}^{\text {Inv }}$ is the dummy denoting whether firm $i$ located in province $p$ and active in sector $s$ engaged in GIS. ENPO_p $c_{p}$ is our proxy for the local ENPOs. $X_{i}$ and $Z_{p}$ are two vectors containing firmand province-level factors.

In all the estimates we also control for 2-digit NACE sector $\left(\eta_{s}\right)$ and NUTS2 region-fixed effects $\left(\gamma_{r}\right)$. Sector-fixed effects account for both the pollution- and energy-intensity of firms' main activity, which can be related to different stringency degrees in the environmental regulations. Furthermore, region fixed-effects capture a different enforcement of environmental regulations and a different commitment of local authorities. While environmental legislation is mainly attributed to the decisions of the central national government, important interventions and duties are appointed and decentralized to the autonomy of NUTS2 regions, which can play an important role for the promotion of clean technologies and sustainable development strategies, the spread of environmental information and education and the prevention of environmental degradation. The investigated effect is then identified across heterogeneous provinces, but within homogeneous areas in terms of regional policy interventions, policy enforcement, economic conditions and social background.

Since our variable of interest $\left(E N P O_{-} p c_{p}\right)$ presents a higher aggregation than the dependent variable, we compute heteroskedasticityconsistent standard errors which are clustered at provincial level in order to correct for within-group correlation (Moulton, 1990).

Estimation of model (1) may be affected by a mild potential selection bias stemming from the definition of Green ${ }_{i p s}^{I n v}$ just on the sample of investors. We then estimate a probit model with sample selection (Heckman, 1979) by means of maximum-likelihood. The selection model consists of modeling the determinants of firms' investment choice, as reflected by a dummy (invest) taking value 1 for firms engaging in tangible investments regardless of the underlying motivation - and 0 for non-investors. As exclusion restriction affecting selection, we use an indicator of credit constraints experienced by a firm (credit_constr) (source: Capitalia), which measures the banking system's refusal to grant further credit. While access to external financial resources allows firms to engage in the investment activity (Stiglitz and Weiss, 1981), it is unlikely to affect the motivation underlying the investment decisions.

All firm-level variables refer either to the three-year period 20012003 as our dependent variable $\left(\right.$ Green $\left._{i p s}^{I n v}\right)$ or, when time-varying information is available, to the year 2001. Our variable of interest $\left(E N P{ }_{-} p c_{p}\right)$ is measured at time 1999 , which is the year when Istat conducted the first census on NPOs.

The use of a pre-sample value helps in mitigating any potential simultaneity concern in our analysis and allows for a time lag in the response of firms to ENPOs' expansion. In order to identify the

\footnotetext{
9 The estimation of a logit model yields exactly the same results both in terms of significance and magnitude of the effect. Also, according to the Akaike Information Criterion (AIC) and Bayesian Information Criterion (BIC), the two models are substantially equivalent. We then decided to stick to the probit model. The estimation of a linear probability model (LPM) instead, even if yields similar findings and magnitude of the effect, delivers a lower goodness of fit with respect to probit and logit models according to the AIC and BIC criteria. Logit estimations and LPM estimations are available upon request.
}

effect of local ENPOs, province-level information is retrieved for the same year 1999, and, when this was not possible, for either 2000 or 2001.

\section{Results}

\subsection{The Impact of ENPOs on Firms' GIS}

Table 1 presents the baseline results and reports marginal effects associated to each factor under investigation. In columns 1-2 we address the potential selection bias resulting from the fact that not all firms in our sample invest in tangible assets. We estimate, by maximum-likelihood, the Eq. (1), which models the importance of the reduction of the environmental impact as a motivation driving firms' tangible investments, together with a selection equation, which models a firm's probability to invest in tangible assets. This corresponds to implementing a Heckprobit estimation. The results suggest that local ENPOs do not exert any influence on firms' investment decisions, but display a positive and significant association with the importance firms attach to the reduction of the environmental impact when undertaking tangible investments. Other potential societal stakeholders, as proxied by non-ENPOs, do not play instead any role. ${ }^{10}$

Evidence on the drivers of investment decisions is in line with our expectations and existing literature. Larger firms, R\&D performers and firms endowed with higher capital intensity are more likely to engage in tangible investments. The importance of provincial customers, as reflected by the provincial market share, promotes firms' investments. Importantly, the indicator of credit constraints, which represents our exclusion restriction, is significant and reveals a lower investment propensity for firms which face difficulties in collecting financial resources from the banking sector. ${ }^{11}$

Focusing on the determinants of GIS, firm size, capital intensity and R\&D status display a significant coefficient, which highlights the importance of internal resources and technology-push factors (Cainelli et al., 2015). Variables capturing market-pull factors are significantly related to firms' GIS. Other firm-level characteristics do not play a significant role. In terms of province-level controls, the share of sorted waste collection has a positive impact on firms' GIS and could reflect beneficial effects stemming from a stricter enforcement of regulations.

The non-significance of the Wald test of independent equations reveals that there is no correlation between the two equations for Green $^{I n v}$ and invest. This finding suggests that sample selection is not an issue in our estimation. We then discard the selection equation and estimate probit models by just focusing on firms' probability to undertake GIS.

Column 3 reports the baseline results gathered from the probit model that substantially replicate the ones discussed above. In Columns 4-5 we then prove that the positive impact of ENPOs is confined to GIS engagement by family firms. ${ }^{12}$ As expected, no significant effect is detected for the sample of non-family firms, which do not seem to be responsive to the pressure exerted by local ENPOs. Moving to the magnitude of our finding, in column 4 we find that a $100 \%$ increase in the provincial number of ENPOs per capita drives to a 14.8 percentage-point increase in the probability that family firms are driven by environment-based motivations in their GIS.

\footnotetext{
10 ENPO_p $c_{p}$ and non $-E N P O_{-} p c_{p}$ are correlated at 0.68 , but this correlation does not sensitively affect the $E N P{ }_{-} p c_{p}$ coefficient, when we discard non $-E N P O_{-} p c_{p}$.

11 We do not find any significant effect when the credit constraint indicator is included in the model estimating the likelihood of GIS adoption.

12 In column [4] the variable group is omitted as we exclude firms belonging to any group in our definition of family firms.
} 
More intuitively, comparing provinces at the 25th and 75th percentile of the distribution of $E N P O \_p c_{p}$, which are Reggio Calabria and Ascoli Piceno respectively, we find that the same family firm would present a 9.33 percentage-point higher probability to engage in GIS if it is located in Ascoli Piceno compared if it were located in Reggio Calabria. Given the share of family firms which are driven by environmental motivations in their investment activities - $48.28 \%$ the presence of local ENPOs emerges to be not only a statistically but also an economically significant driver affecting family firms' GIS engagement. Hypothesis 1 is then confirmed.

\subsection{Identification and Robustness}

We implement a number of identification tests and sensitivity checks to validate our findings.

First, we test the robustness of our results to the use of alternative dependent and independent variables, as reported in Table 2. In columns 1-3 we investigate an ordinal dependent variable instead of our binary variable. The ordinal dependent variable assumes value 1 if the firm's assessment of the importance of "environmental impact reduction" as motivation of tangible investments is "low", 2 if the firm's assessment is "medium", and 3 if it is "high". In column 1 we implement an ordered probit, while in columns 2-3 we adopt a multinomial logit, which compares ${ }^{13}$ firms assessing the importance of "environmental impact reduction" as "high" and "medium" with those firms assessing the importance of "environmental impact reduction" as "low". Both estimations confirm our results. It is worth noting that we do not find any significant difference in the ENPOs influence on firms assessing the importance of their "environmental impact" as "high" versus those assessing it as "medium", with the latter displaying a slightly higher coefficient.

In columns 4-5 we extend our analysis by exploring the amount of firms' environmental investments. To remedy the lack of direct information on such investments, we follow two strategies. In column 4 we use the total investment amount of firms over the period 2001-2003, and create a variable Green ${ }^{\text {ValueA }}$ equal to this amount when Green ${ }^{\text {Inv }}$ takes value 1, and 0 when Green $^{\text {Inv }}$ takes value 0 . In column 5 , instead, we divide the total investment amounts among all the objectives a firm declares to pursue ${ }^{14}$ by attributing to each objective the same investment share, Green ${ }^{V \text { alueB }}$. In both cases, we estimate a tobit model and we corroborate our findings. ${ }^{15}$

In column 6, we then test the robustness of our empirical strategy by substituting the share of volunteers in ENPOs over provincial population for the log number of ENPOs per capita. ${ }^{16}$

\footnotetext{
13 We cannot implement a multiprobit model due to the presence of a large set of fixed effects that do not allow the model to convergence.

14 For all the possible objectives listed in the survey (i.e., improvement of existing products' quality; expansion of existing products' production value; introduction of new products; reduction of the environmental impact; reduction of the use of raw materials; reduction of the use of workforce), we build a dummy variable equal to 1 if firms declare to assess that objective as being of either "high" or "medium" importance, 0 otherwise, as in the construction of our dependent variable Green $^{\text {Inv }}$.

15 We lose some observations due to missing values for the investment amount.

16 The 1999 Census reports a suspicious value of this variable for the province of Turin, and this anomaly is confirmed when we compare the 1999 value with the value retrieved from the 2011 Census. To remedy to this, we replaced this value by discounting the 2011 value with the 2011/1999 growth rate in the number of ENPOs in the Piedmont region (the NUTS2 region where Turin is located) by excluding Turin. We also tried to discount the 2011 value with the 2011/1999 growth rate of ENPOs in Italy (by excluding Turin) and the growth in the number of other NPOs in Turin. We have then re-estimated the model by discarding the province of Turin. All these estimations confirm the main findings and are available upon request.
}

We also estimate the baseline model by excluding all firmand province-level covariates in order to rule out any collinearity concern. Our main findings stay substantially unchanged. These results are not reported, but available from the authors upon request.

In Table 3 we account for potential endogeneity issues by testing for observable omitted variables and reverse causality concerns. In columns 1-2, borrowing from Mazzanti et al. (2011) we test for decentralized policy interventions in the waste management. In particular, in 1997 Italy issued the 22/1997 Law, which introduced a new waste system based on a full-cost pricing tariff instead of the old tax that was related to the size of household living spaces. The new legislation did not completely abolish the previous tax, but allowed for a transition period. The adoption of this new tariff-based system could, thus, reflect the level of policy commitment at province-level and then proxy the role of regulatory stakeholders. Despite the control for region dummies, differences in environmental regulations across provinces could still affect our baseline findings. Thus, we include the share of provincial municipalities (newwaste ShMunicipalities $^{\text {) }}$ and the share of provincial population (newwaste $e^{\text {ShPop }}$ ) covered by the new tariff respectively, in the model. Both indicators refer to the year 2000 and are retrieved from the 2001 Italian Environmental Agency's waste report (source: APAT 2001).

We then control for social capital. Higher level of social capital reflects higher altruism and interest for third parties, and this could drive a higher propensity of firms to take the responsibility of their actions and adopt social responsible behaviors. In column 3, we include an index of social capital (soc_capital ${ }_{p}$ ) $\left(\right.$ Cartocci, 2007) ${ }^{17}$. In column 4 , we control for the size of the informal sector (informal ) estimated for the province in 2003 (source: Istat). The latter indicator can capture both the level of legality and the altruistic values spread in a territory.

In column 5, we further include in our estimates a variable capturing the share of adult population with secondary education (secondary_edu $u_{p}$ ) (source: Istat). A lower education level, indeed, could reduce damages awarded to polluting firms in case of environmental accidents or any lawsuits for environmental responsibility (Becker, 2003). While all additional controls do not bear a significant coefficient, the effect captured by our variable of interest is not affected.

In column 6 we substitute 2-digit for 4-digit NACE sector fixedeffects. This allows to capture the heterogeneity in pollution and energy intensity across very detailed sectors, at the cost of a small drop in the number of observations. Some sector dummies, indeed, perfectly predicts the probability to engage in GIS for some firms. Again, no significant difference is disclosed in our estimations and the coefficient even slightly increases in the magnitude. ${ }^{18}$

These analyses show that our result is robust to the control of observable omitted variables.

\footnotetext{
17 Cartocci (2007) computes a synthetic index of social capital which is obtained by implementing a principal component analysis on four different variables: average turnout in national elections, European elections, and referenda during the 1990s; newspapers diffusion; membership to sport associations; blood donations. We follow existing literature (Nannicini et al., 2013) and we exploit this indicator to capture social capital spread across Italian provinces. In particular we follow Guiso et al. (2010) and exploit a notion of social capital reflecting civic capital, that is "those persistent and shared beliefs and values that help a group overcome the free rider problem in the pursuit of socially valuable activities".

18 We also test the robustness of our results to the inclusion of a number of variables capturing the international involvement of both firms and provinces based on a growing literature supporting the existence of a significant nexus between firms' internationalization and green attitude (Cole et al., 2008; De Marchi, 2012). These results, which are available from the authors upon request, replicate the main findings.
} 
Table 1

The role of local ENPOs in firms' GIS engagement ${ }^{a}$.

\begin{tabular}{|c|c|c|c|c|c|}
\hline & \multicolumn{2}{|l|}{ Heckman } & \multirow[t]{2}{*}{ Baseline } & \multirow[t]{2}{*}{ Family } & \multirow[t]{2}{*}{ Non-family } \\
\hline & Green $^{\text {Inv }}$ & invest & & & \\
\hline & [1] & [2] & [3] & [4] & [5] \\
\hline \multirow{2}{*}{$E N P O s_{-} p c_{p}$} & $0.085^{* * *}$ & 0.022 & $0.081^{* * *}$ & $0.148^{* * *}$ & 0.039 \\
\hline & {$[0.026]$} & {$[0.018]$} & [0.025] & {$[0.035]$} & {$[0.036]$} \\
\hline \multirow[t]{2}{*}{$n o n-E N P O s \_p c_{p}$} & -0.03 & -0.041 & -0.036 & -0.107 & 0.023 \\
\hline & [0.049] & {$[0.030]$} & [0.047] & [0.067] & [0.067] \\
\hline \multirow[t]{2}{*}{ mkt_prov } & $0.001^{* *}$ & $0.001^{* *}$ & $0.001^{* *}$ & 0.001 & $0.001^{* * *}$ \\
\hline & {$[0.000]$} & {$[0.000]$} & {$[0.000]$} & {$[0.001]$} & {$[0.001]$} \\
\hline \multirow[t]{2}{*}{ satisfaction } & $0.045^{* *}$ & 0.008 & $0.044^{* *}$ & 0.048 & $0.049^{*}$ \\
\hline & [0.023] & {$[0.016]$} & {$[0.022]$} & {$[0.037]$} & {$[0.028]$} \\
\hline \multirow[t]{2}{*}{ quality_cert } & $0.057^{* *}$ & 0.002 & $0.059^{* * * *}$ & 0.019 & $0.100^{* * *}$ \\
\hline & {$[0.023]$} & {$[0.018]$} & {$[0.022]$} & {$[0.034]$} & {$[0.031]$} \\
\hline \multirow{2}{*}{ education } & -0.025 & -0.027 & -0.016 & -0.045 & -0.01 \\
\hline & {$[0.050]$} & {$[0.025]$} & [0.049] & {$[0.070]$} & {$[0.055]$} \\
\hline \multirow[t]{2}{*}{ rd_status } & $0.091^{* * *}$ & $0.125^{* * *}$ & $0.092^{* * * *}$ & $0.128^{* * *}$ & $0.075^{* *}$ \\
\hline & {$[0.020]$} & {$[0.012]$} & [0.019] & {$[0.029]$} & [0.032] \\
\hline \multirow[t]{2}{*}{ group } & 0.002 & -0.008 & 0.004 & & -0.01 \\
\hline & {$[0.021]$} & {$[0.018]$} & {$[0.021]$} & & {$[0.028]$} \\
\hline \multirow[t]{2}{*}{ patent $^{\text {For }}$} & 0.096 & 0.03 & 0.098 & 0.123 & 0.08 \\
\hline & {$[0.075]$} & {$[0.066]$} & {$[0.074]$} & [0.131] & {$[0.090]$} \\
\hline \multirow[t]{2}{*}{ age } & 0.008 & -0.005 & 0.008 & 0.023 & 0.001 \\
\hline & {$[0.021]$} & {$[0.010]$} & {$[0.018]$} & {$[0.027]$} & {$[0.021]$} \\
\hline \multirow[t]{2}{*}{ size } & $0.041^{* *}$ & $0.053^{* * *}$ & $0.037^{* *}$ & -0.01 & $0.055^{* * *}$ \\
\hline & {$[0.016]$} & {$[0.010]$} & {$[0.014]$} & {$[0.024]$} & [0.015] \\
\hline \multirow[t]{2}{*}{$k l$} & $0.020^{*}$ & $0.022^{* * *}$ & $0.019^{*}$ & 0.018 & 0.016 \\
\hline & {$[0.011]$} & {$[0.007]$} & {$[0.011]$} & {$[0.015]$} & {$[0.012]$} \\
\hline \multirow{2}{*}{ waste $_{p}^{\text {sorted }}$} & $0.003^{* *}$ & $0.003^{*}$ & $0.003^{* *}$ & $0.004^{*}$ & 0.002 \\
\hline & [0.001] & {$[0.002]$} & {$[0.001]$} & {$[0.002]$} & {$[0.002]$} \\
\hline \multirow[t]{2}{*}{$v a_{-} p c_{p}$} & -0.004 & -0.007 & -0.01 & -0.112 & 0.056 \\
\hline & [0.048] & {$[0.037]$} & [0.047] & {$[0.072]$} & [0.055] \\
\hline \multirow[t]{2}{*}{$e m p \_s h_{p}$} & -0.074 & 0.077 & -0.087 & -0.509 & 0.253 \\
\hline & {$[0.285]$} & {$[0.261]$} & [0.271] & [0.498] & [0.428] \\
\hline \multirow[t]{2}{*}{ cred_cons } & & $-0.061^{* *}$ & & & \\
\hline & & {$[0.030]$} & & & \\
\hline Observations & 2620 & 2620 & 2275 & 986 & 1288 \\
\hline Log-Lik & -2394.899 & -2394.899 & & & \\
\hline Censored & 375 & 375 & & & \\
\hline$\rho$ & -0.087 & -0.087 & & & \\
\hline Wald-Indep P-value & 0.914 & 0.914 & & & \\
\hline Pseudo $\mathrm{R}^{2}$ & & & 0.056 & 0.069 & 0.084 \\
\hline P-value difference & & & & & \\
\hline \multicolumn{6}{|l|}{ Fixed effects } \\
\hline 2-digit Sector & Yes & Yes & Yes & Yes & Yes \\
\hline NUTS2 Region & Yes & Yes & Yes & Yes & Yes \\
\hline
\end{tabular}

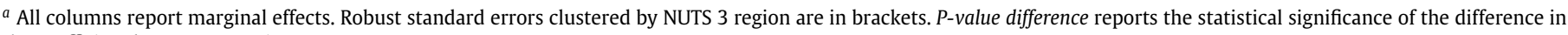
the coefficient between equations.

${ }^{*} p<10 \%$; ${ }^{* *} p<5 \%$ level; ${ }^{* * *} p<1 \%$

The analysis of the effect of an aggregated indicator (ENPOs) on a microeconomic outcome (firms GIS) helps mitigate any further endogeneity issue. Furthermore, if our estimation was affected by a potential reverse causality, the latter would presumably drive to a downward bias of the estimated coefficient associated to ENPOs and, as a consequence, our result would be, at worst, a lower bound estimate of the real effect of ENPOs on firms' GIS. Indeed, we eventually expect that firms' harmful behaviors for the environment would engender the reaction of civil society and the creation of new ENPOs. If this effect was in force and was affecting our estimation, the effect of ENPOs would be even stronger than the one we have detected. To directly address the reverse causality concern, we implement an instrumental variable approach on the probit model in Eq. (1). We exploit two province-level variables as instruments. The first is the rainfall per squared kilometer in the province (rainfall) (source: Istat, 1997 Statistiche Metereologiche), which has been found by the literature as reducing air pollution (Ouyang et al., 2015). A high level of rainfall, by improving the air quality could actually reduce the incentive and need for ENPOs pressure. We then expect this variable to be negatively associated to the variable of our interest, ENPOs_pc. The second instrument is an indicator that captures the level of provincial unused housing stock (unused_housing) measuring the number of housing facilities which are not exploited (source: Istat). We expect this indicator to be positively associated with the presence of ENPOs since it would reflect a lower care for the existing residential housing stock and a consequent ENPOs pressure to protect the territory. The first stage estimation delivers the expected results on the relationship between ENPOs_pc and the two instruments. ${ }^{19}$

\footnotetext{
19 Findings are confirmed when we implement the instrumental variable approach on a linear probability model. In this case, the Hansen test reveals the validity of our instruments and F-tests of the first stage confirm the strength of the instruments we exploit.
} 
Table 2

Alternative dependent and independent variables ${ }^{a}$.

\begin{tabular}{|c|c|c|c|c|c|c|}
\hline & \multirow{2}{*}{$\frac{\text { Ordered }}{\text { Probit }}$} & \multicolumn{2}{|c|}{ Multinomial logit } & \multirow[t]{2}{*}{ Green $^{\text {ValueA }}$} & \multirow[t]{2}{*}{ Green $^{\text {ValueB }}$} & \multirow[t]{2}{*}{ ENPOs_vol $l_{p}$} \\
\hline & & High & Medium & & & \\
\hline & [1] & [2] & [3] & [4] & [5] & [6] \\
\hline$E N P O s \_p c_{p}$ & $\begin{array}{c}0.310^{* * *} \\
{[0.089]}\end{array}$ & $\begin{array}{l}0.503^{* *} \\
{[0.220]}\end{array}$ & $\begin{array}{c}0.722^{* * *} \\
{[0.199]}\end{array}$ & $\begin{array}{c}4.132^{* * *} \\
{[1.073]}\end{array}$ & $\begin{array}{c}3.719^{* * *} \\
{[0.958]}\end{array}$ & \\
\hline$E_{N P O s \_v o l}$ & & & & & & $\begin{array}{c}43.439^{* * *} \\
{[16.717]}\end{array}$ \\
\hline$n o n-E N P O s \_p c_{p}$ & $\begin{array}{c}-0.286^{*} \\
{[0.148]}\end{array}$ & $\begin{array}{c}-0.620^{* *} \\
{[0.312]}\end{array}$ & $\begin{array}{l}-0.357 \\
{[0.372]}\end{array}$ & $\begin{array}{l}-2.676 \\
{[1.906]}\end{array}$ & $\begin{array}{l}-2.525 \\
{[1.698]}\end{array}$ & $\begin{array}{l}-0.019 \\
{[0.062]}\end{array}$ \\
\hline mkt_prov & $\begin{array}{c}0.001 \\
{[0.002]}\end{array}$ & $\begin{array}{c}0.002 \\
{[0.004]}\end{array}$ & $\begin{array}{c}0.003 \\
{[0.003]}\end{array}$ & $\begin{array}{c}0.016 \\
{[0.016]}\end{array}$ & $\begin{array}{c}0.014 \\
{[0.014]}\end{array}$ & $\begin{array}{c}0.001 \\
{[0.001]}\end{array}$ \\
\hline satisfaction & $\begin{array}{c}0.101 \\
{[0.092]}\end{array}$ & $\begin{array}{c}0.181 \\
{[0.229]}\end{array}$ & $\begin{array}{c}0.21 \\
{[0.196]}\end{array}$ & $\begin{array}{c}1.19 \\
{[1.106]}\end{array}$ & $\begin{array}{c}1.005 \\
{[0.982]}\end{array}$ & $\begin{array}{c}0.048 \\
{[0.037]}\end{array}$ \\
\hline quality_cert & $\begin{array}{c}0.087 \\
{[0.087]}\end{array}$ & $\begin{array}{c}0.316 \\
{[0.221]}\end{array}$ & $\begin{array}{l}-0.046 \\
{[0.185]}\end{array}$ & $\begin{array}{c}0.407 \\
{[1.079]}\end{array}$ & $\begin{array}{c}0.355 \\
{[0.962]}\end{array}$ & $\begin{array}{c}0.015 \\
{[0.034]}\end{array}$ \\
\hline education & $\begin{array}{c}-0.02 \\
{[0.187]}\end{array}$ & $\begin{array}{c}0.105 \\
{[0.459]}\end{array}$ & $\begin{array}{l}-0.381 \\
{[0.343]}\end{array}$ & $\begin{array}{c}-1.05 \\
{[2.083]}\end{array}$ & $\begin{array}{l}-0.992 \\
{[1.855]}\end{array}$ & $\begin{array}{l}-0.047 \\
{[0.070]}\end{array}$ \\
\hline rd_status & $\begin{array}{c}0.265^{* * *} \\
{[0.081]}\end{array}$ & $\begin{array}{l}0.472^{* *} \\
{[0.208]}\end{array}$ & $\begin{array}{c}0.622^{* * *} \\
{[0.147]}\end{array}$ & $\begin{array}{c}3.848^{* * * *} \\
{[0.835]}\end{array}$ & $\begin{array}{c}3.379^{* * *} \\
{[0.745]}\end{array}$ & $\begin{array}{c}0.129^{* * *} \\
{[0.029]}\end{array}$ \\
\hline patent $^{\text {For }}$ & $\begin{array}{c}0.349 \\
{[0.355]}\end{array}$ & $\begin{array}{c}0.862 \\
{[0.794]}\end{array}$ & $\begin{array}{c}0.272 \\
{[0.626]}\end{array}$ & $\begin{array}{c}3.861 \\
{[3.246]}\end{array}$ & $\begin{array}{c}3.536 \\
{[2.894]}\end{array}$ & $\begin{array}{c}0.097 \\
{[0.130]}\end{array}$ \\
\hline age & $\begin{array}{c}0.033 \\
{[0.070]}\end{array}$ & $\begin{array}{c}0.012 \\
{[0.170]}\end{array}$ & $\begin{array}{c}0.166 \\
{[0.138]}\end{array}$ & $\begin{array}{c}0.593 \\
{[0.759]}\end{array}$ & $\begin{array}{c}0.523 \\
{[0.672]}\end{array}$ & $\begin{array}{c}0.022 \\
{[0.028]}\end{array}$ \\
\hline size & $\begin{array}{l}-0.054 \\
{[0.058]}\end{array}$ & $\begin{array}{l}-0.177 \\
{[0.144]}\end{array}$ & $\begin{array}{c}0.031 \\
{[0.131]}\end{array}$ & $\begin{array}{c}0.393 \\
{[0.716]}\end{array}$ & $\begin{array}{c}0.408 \\
{[0.637]}\end{array}$ & $\begin{array}{c}-0.008 \\
{[0.024]}\end{array}$ \\
\hline$k l$ & $\begin{array}{c}0.062 * \\
{[0.037]}\end{array}$ & $\begin{array}{c}0.151^{*} \\
{[0.085]}\end{array}$ & $\begin{array}{c}0.025 \\
{[0.079]}\end{array}$ & $\begin{array}{c}0.538 \\
{[0.448]}\end{array}$ & $\begin{array}{c}0.518 \\
{[0.398]}\end{array}$ & $\begin{array}{c}0.019 \\
{[0.016]}\end{array}$ \\
\hline waste $_{p}^{\text {sorted }}$ & $\begin{array}{c}0.006 \\
{[0.005]}\end{array}$ & $\begin{array}{c}0.003 \\
{[0.011]}\end{array}$ & $\begin{array}{l}0.026^{* *} \\
{[0.011]}\end{array}$ & $\begin{array}{c}0.104 \\
{[0.064]}\end{array}$ & $\begin{array}{c}0.092 \\
{[0.057]}\end{array}$ & $\begin{array}{c}0.005^{*} \\
{[0.002]}\end{array}$ \\
\hline$v a \_p c_{p}$ & $\begin{array}{c}-0.21 \\
{[0.203]}\end{array}$ & $\begin{array}{l}-0.255 \\
{[0.526]}\end{array}$ & $\begin{array}{c}-0.671^{*} \\
{[0.364]}\end{array}$ & $\begin{array}{l}-3.156 \\
{[2.301]}\end{array}$ & $\begin{array}{l}-2.818 \\
{[2.071]}\end{array}$ & $\begin{array}{l}-0.123 \\
{[0.083]}\end{array}$ \\
\hline$e m p \_s h_{p}$ & $\begin{array}{c}-0.73 \\
{[1.177]}\end{array}$ & $\begin{array}{l}-0.378 \\
{[2.833]}\end{array}$ & $\begin{array}{l}-3.577 \\
{[2.868]}\end{array}$ & $\begin{array}{l}-13.795 \\
{[15.138]}\end{array}$ & $\begin{array}{l}-12.661 \\
{[13.564]}\end{array}$ & $\begin{array}{l}-0.165 \\
{[0.475]}\end{array}$ \\
\hline Observations & 986 & 986 & 986 & 946 & 946 & 986 \\
\hline Pseudo $\mathrm{R}^{2}$ & 0.0504 & 0.087 & 0.087 & & & 0.066 \\
\hline Sigma & & & & $\begin{array}{c}11.847^{* * *} \\
{[0.394]}\end{array}$ & $\begin{array}{c}10.533^{* * *} \\
{[0.348]}\end{array}$ & \\
\hline
\end{tabular}

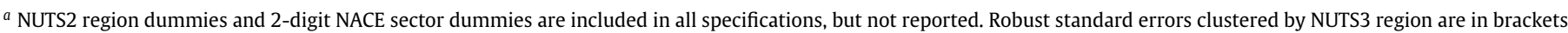
Columns [4] and [5] report results from Tobit estimations.

${ }^{*} p<10 \%$; ** $p<5 \%$; *** $p<1 \%$.

The second stage estimation substantially corroborates the baseline estimation and the exogeneity test, reported at the bottom of the table, suggests that endogeneity is not a concern in our setting. We then rest on baseline probit estimation for the remaining of the paper.

\subsection{The Substitutability Between ENPOs and Sectoral Regulations}

To test Hypothesis 2, in Table 4 we add an interaction term between our proxy for local ENPOs $\left(E N P O_{-} p c_{p}\right)$ and the sector-level indicator of environmental stringency (env_string). We proceed by exploiting two different proxies for regulations. In columns 1-2 we measure environmental stringency with the sector-level environmental taxes over value added (source: Eurostat). In columns 3-6, we use sectoral emissions. In particular, sectors that are more pollution-intensive and release substantial amounts of emissions are those that are more likely to attract policy makers' attention and, then, to be subject to stricter regulations. ${ }^{20}$ Higher emissions

20 An example is represented by the EU Emission Trade System that mainly regulates carbon dioxide emissions of energy and pollution intensive sectors. per unit of value added then represent a good proxy for regulation stringency. Specifically, we consider $\mathrm{CO}_{2}$ emissions, an indicator of GWP and an indicator of acidification. In columns 1, 3, 5 and 7, we add the interaction between $E N P O \_p c_{p}$ and the dummy env_string ${ }^{D}$, which identifies sectors with values of environmental stringency above the median, to our baseline specification. While in columns $2,4,6$, and 8 we replace the dummy variable with the continuous value of environmental stringency (env_string), being the environmental taxes per unit of value added or emissions per unit of value added.

We find a negative and significant coefficient on the interaction term irrespective of the indicator (i.e., environmental taxes or emissions) and the measure (i.e., binary or continuous variable) used to proxy for regulations. Since we control for 2-digit sector fixed effects, our model does not include either the binary or the continuous term associated to environmental taxes and emissions. Although our interest does not rely on the importance of regulations, when we drop sector dummies, env_string bears a positive and highly significant coefficient.

We conclude that ENPO_p $c_{p}$ is significant only for family firms active in sectors exposed to lower levels of environmental stringency. Our finding then shows that ENPOs act as substitute for 
Table 3

Robustness and identification ${ }^{a}$.

\begin{tabular}{|c|c|c|c|c|c|c|c|c|}
\hline & & & & & & \multirow{2}{*}{$\frac{4 \text { digit }}{\text { Dummies }}$} & \multicolumn{2}{|c|}{ Instrumental variable } \\
\hline & & & & & & & Second stage & First stage \\
\hline & [1] & [2] & [3] & {$[4]$} & {$[5]$} & [6] & [7] & [8] \\
\hline$E N P O s \_p c_{p}$ & $\begin{array}{c}0.150^{* * * *} \\
{[0.034]}\end{array}$ & $\begin{array}{c}0.151^{* * * *} \\
{[0.033]}\end{array}$ & $\begin{array}{c}0.147^{* * *} \\
{[0.034]}\end{array}$ & $\begin{array}{c}0.148^{* * * *} \\
{[0.035]}\end{array}$ & $\begin{array}{c}0.137^{* * *} \\
{[0.038]}\end{array}$ & $\begin{array}{c}0.176^{* * *} \\
{[0.040]}\end{array}$ & $\begin{array}{l}0.149^{* *} \\
{[0.075]}\end{array}$ & \\
\hline newwaste $e_{p}^{\text {ShMunicipalities }}$ & $\begin{array}{c}0.001 \\
{[0.002]}\end{array}$ & & & & & & & \\
\hline newwaste ${ }_{p}^{\text {ShPop }}$ & & $\begin{array}{c}0.001 \\
{[0.001]}\end{array}$ & & & & & & \\
\hline soc_capital $_{p}$ & & & $\begin{array}{c}0.024 \\
{[0.015]}\end{array}$ & & & & & \\
\hline informal $_{p}$ & & & & $\begin{array}{l}-0.003 \\
{[0.007]}\end{array}$ & & & & \\
\hline secondary_edu $u_{p}$ & & & & & $\begin{array}{l}-0.308 \\
{[0.331]}\end{array}$ & & & \\
\hline$n o n-E N P O s \_p c_{p}$ & $\begin{array}{l}-0.109 \\
{[0.067]}\end{array}$ & $\begin{array}{l}-0.109 \\
{[0.067]}\end{array}$ & $\begin{array}{c}-0.127^{*} \\
{[0.068]}\end{array}$ & $\begin{array}{c}-0.111^{*} \\
{[0.066]}\end{array}$ & $\begin{array}{c}-0.104 \\
{[0.066]}\end{array}$ & $\begin{array}{l}-0.037 \\
{[0.073]}\end{array}$ & $\begin{array}{r}-0.109 \\
{[0.100]}\end{array}$ & $\begin{array}{c}0.871^{* * * *} \\
{[0.102]}\end{array}$ \\
\hline mkt_prov & $\begin{array}{c}0.001 \\
{[0.001]}\end{array}$ & $\begin{array}{c}0.001 \\
{[0.001]}\end{array}$ & $\begin{array}{c}0.001 \\
{[0.001]}\end{array}$ & $\begin{array}{c}0.001 \\
{[0.001]}\end{array}$ & $\begin{array}{c}0.001 \\
{[0.001]}\end{array}$ & $\begin{array}{c}0.001 \\
{[0.001]}\end{array}$ & $\begin{array}{c}0.001 \\
{[0.001]}\end{array}$ & $\begin{array}{c}0 \\
{[0.000]}\end{array}$ \\
\hline satisfaction & $\begin{array}{c}0.047 \\
{[0.037]}\end{array}$ & $\begin{array}{c}0.046 \\
{[0.037]}\end{array}$ & $\begin{array}{c}0.053 \\
{[0.037]}\end{array}$ & $\begin{array}{c}0.047 \\
{[0.037]}\end{array}$ & $\begin{array}{c}0.047 \\
{[0.037]}\end{array}$ & $\begin{array}{c}0.067^{*} \\
{[0.040]}\end{array}$ & $\begin{array}{c}0.048 \\
{[0.037]}\end{array}$ & $\begin{array}{c}0.006 \\
{[0.017]}\end{array}$ \\
\hline quality_cert & $\begin{array}{c}0.019 \\
{[0.035]}\end{array}$ & $\begin{array}{c}0.019 \\
{[0.035]}\end{array}$ & $\begin{array}{c}0.013 \\
{[0.035]}\end{array}$ & $\begin{array}{c}0.019 \\
{[0.034]}\end{array}$ & $\begin{array}{c}0.02 \\
{[0.035]}\end{array}$ & $\begin{array}{c}0.005 \\
{[0.035]}\end{array}$ & $\begin{array}{c}0.019 \\
{[0.034]}\end{array}$ & $\begin{array}{l}-0.024 \\
{[0.021]}\end{array}$ \\
\hline education & $\begin{array}{l}-0.045 \\
{[0.070]}\end{array}$ & $\begin{array}{l}-0.045 \\
{[0.070]}\end{array}$ & $\begin{array}{l}-0.049 \\
{[0.071]}\end{array}$ & $\begin{array}{l}-0.046 \\
{[0.070]}\end{array}$ & $\begin{array}{c}-0.043 \\
{[0.070]}\end{array}$ & $\begin{array}{l}-0.051 \\
{[0.075]}\end{array}$ & $\begin{array}{l}-0.045 \\
{[0.071]}\end{array}$ & $\begin{array}{c}0.053 \\
{[0.035]}\end{array}$ \\
\hline rd_status & $\begin{array}{c}0.129^{* * *} \\
{[0.029]}\end{array}$ & $\begin{array}{c}0.129 * * * \\
{[0.029]}\end{array}$ & $\begin{array}{c}0.132^{* * *} \\
{[0.029]}\end{array}$ & $\begin{array}{c}0.128^{* * *} \\
{[0.029]}\end{array}$ & $\begin{array}{c}0.128^{* * * *} \\
{[0.029]}\end{array}$ & $\begin{array}{c}0.135^{* * *} \\
{[0.030]}\end{array}$ & $\begin{array}{c}0.128^{* * *} \\
{[0.028]}\end{array}$ & $\begin{array}{c}0.018 \\
{[0.017]}\end{array}$ \\
\hline patent $^{\text {For }}$ & $\begin{array}{c}0.123 \\
{[0.131]}\end{array}$ & $\begin{array}{c}0.12 \\
{[0.130]}\end{array}$ & $\begin{array}{c}0.134 \\
{[0.133]}\end{array}$ & $\begin{array}{c}0.122 \\
{[0.130]}\end{array}$ & $\begin{array}{c}0.124 \\
{[0.130]}\end{array}$ & $\begin{array}{c}0.144 \\
{[0.152]}\end{array}$ & $\begin{array}{c}0.123 \\
{[0.131]}\end{array}$ & $\begin{array}{c}-0.03 \\
{[0.056]}\end{array}$ \\
\hline age & $\begin{array}{c}0.024 \\
{[0.027]}\end{array}$ & $\begin{array}{c}0.024 \\
{[0.027]}\end{array}$ & $\begin{array}{c}0.023 \\
{[0.027]}\end{array}$ & $\begin{array}{c}0.022 \\
{[0.027]}\end{array}$ & $\begin{array}{c}0.024 \\
{[0.028]}\end{array}$ & $\begin{array}{c}0.017 \\
{[0.035]}\end{array}$ & $\begin{array}{c}0.023 \\
{[0.027]}\end{array}$ & $\begin{array}{l}-0.023 \\
{[0.016]}\end{array}$ \\
\hline size & $\begin{array}{l}-0.011 \\
{[0.024]}\end{array}$ & $\begin{array}{c}-0.011 \\
{[0.024]}\end{array}$ & $\begin{array}{l}-0.011 \\
{[0.024]}\end{array}$ & $\begin{array}{c}-0.01 \\
{[0.024]}\end{array}$ & $\begin{array}{l}-0.011 \\
{[0.024]}\end{array}$ & $\begin{array}{l}-0.029 \\
{[0.025]}\end{array}$ & $\begin{array}{c}-0.01 \\
{[0.024]}\end{array}$ & $\begin{array}{l}-0.006 \\
{[0.010]}\end{array}$ \\
\hline$k l$ & $\begin{array}{c}0.018 \\
{[0.015]}\end{array}$ & $\begin{array}{c}0.018 \\
{[0.015]}\end{array}$ & $\begin{array}{c}0.017 \\
{[0.015]}\end{array}$ & $\begin{array}{c}0.017 \\
{[0.015]}\end{array}$ & $\begin{array}{c}0.017 \\
{[0.015]}\end{array}$ & $\begin{array}{c}0.013 \\
{[0.017]}\end{array}$ & $\begin{array}{c}0.018 \\
{[0.015]}\end{array}$ & $\begin{array}{c}0.005 \\
{[0.009]}\end{array}$ \\
\hline waste ${ }_{p}^{\text {sorted }}$ & $\begin{array}{c}0.004 \\
{[0.002]}\end{array}$ & $\begin{array}{c}0.004^{*} \\
{[0.002]}\end{array}$ & $\begin{array}{c}0.004^{*} \\
{[0.002]}\end{array}$ & $\begin{array}{c}0.004^{*} \\
{[0.002]}\end{array}$ & $\begin{array}{c}0.004^{*} \\
{[0.002]}\end{array}$ & $\begin{array}{c}0.002 \\
{[0.002]}\end{array}$ & $\begin{array}{c}0.004^{*} \\
{[0.002]}\end{array}$ & $\begin{array}{l}0.011^{* *} \\
{[0.005]}\end{array}$ \\
\hline$v a_{-} p c_{p}$ & $\begin{array}{l}-0.113 \\
{[0.072]}\end{array}$ & $\begin{array}{l}-0.112 \\
{[0.072]}\end{array}$ & $\begin{array}{c}-0.126^{*} \\
{[0.076]}\end{array}$ & $\begin{array}{l}-0.117 \\
{[0.074]}\end{array}$ & $\begin{array}{l}-0.088 \\
{[0.067]}\end{array}$ & $\begin{array}{l}-0.037 \\
{[0.108]}\end{array}$ & $\begin{array}{l}-0.112 \\
{[0.073]}\end{array}$ & $\begin{array}{c}0.007 \\
{[0.155]}\end{array}$ \\
\hline$e m p \_s h_{p}$ & $\begin{array}{l}-0.482 \\
{[0.503]}\end{array}$ & $\begin{array}{c}-0.461 \\
{[0.487]}\end{array}$ & $\begin{array}{l}-0.468 \\
{[0.483]}\end{array}$ & $\begin{array}{l}-0.541 \\
{[0.508]}\end{array}$ & $\begin{array}{c}-0.6 \\
{[0.502]}\end{array}$ & $\begin{array}{c}-1.704^{* * *} \\
{[0.581]}\end{array}$ & $\begin{array}{l}-0.512 \\
{[0.527]}\end{array}$ & $\begin{array}{c}0.197 \\
{[1.090]}\end{array}$ \\
\hline unused_housing $_{p}$ & & & & & & & & $\begin{array}{c}0.018^{* * *} \\
{[0.003]}\end{array}$ \\
\hline rainfall $_{p}$ & & & & & & & & $\begin{array}{c}-0.151^{* * *} \\
{[0.047]}\end{array}$ \\
\hline Observations & 986 & 986 & 986 & 986 & 986 & 851 & 986 & 986 \\
\hline Pseudo $\mathrm{R}^{2}$ & 0.069 & 0.069 & 0.071 & 0.069 & 0.069 & 0.146 & & \\
\hline P_exog & & & & & & & 0.983 & 0.983 \\
\hline
\end{tabular}

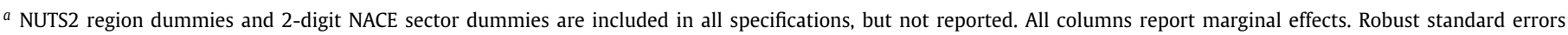
clustered by NUTS3 region are in brackets. P_exog reports the p-value associated to the test of exogeneity.

${ }^{*} p<10 \%$; ${ }^{* *} p<5 \%$; ${ }^{* * *} p<1 \%$.

environmental regulations in promoting GIS engagement by family firms and supports Hypothesis 2.

\section{Conclusions}

Firms' GIS are fundamental to achieve a sustainable economic path because they substantially contribute to gain competitiveness and expand the knowledge stock and innovative capacity of a country. For these reasons both academics and policy-makers have paid increasing attention in understanding the drivers fostering firms' GIS.

We add to this discussion by focusing on the role of ENPOs as a distinctive type of societal stakeholder, and by shedding light on the distinction between family and non-family firms. We suggest that family-firms are more likely to engage in GIS in response to ENPOs' normative pressure than non-family firms due to their resource constraints, which make them less capable to bear the costs of head-to-head confrontation with ENPOs (Gomez-Mejia et al., 2003; Hamelin, 2013; Zellweger and Sieger, 2012), and to the greater value they attach to local socio-emotional rewards that serve as "a form of social insurance in times of crisis" (dye, 2006). Furthermore, we uncover that the normative pressure exerted by local ENPOs substitutes for the coercive pressure of environmental regulation in sectors where regulation is less strict, thus promoting family firms' self-regulatory behaviors. We find empirical support for our arguments on a sample of Italian manufacturing firms. 
Table 4

The role of sectoral regulations.

\begin{tabular}{|c|c|c|c|c|c|c|c|c|}
\hline & \multirow{2}{*}{\multicolumn{2}{|c|}{ Environmental taxes }} & \multicolumn{6}{|l|}{ Emissions } \\
\hline & & & GWP & & $\mathrm{CO} 2$ & & Acidificati & \\
\hline & [1] & {$[2]$} & [3] & {$[4]$} & [5] & {$[6]$} & [7] & [8] \\
\hline$E N P O s \_p c_{p}$ & $\begin{array}{l}0.178^{* * *} \\
{[0.044]}\end{array}$ & $\begin{array}{l}0.214^{* * *} \\
{[0.050]}\end{array}$ & $\begin{array}{l}0.213^{* * *} \\
{[0.043]}\end{array}$ & $\begin{array}{l}0.391^{* * *} \\
{[0.125]}\end{array}$ & $\begin{array}{l}0.213^{* * *} \\
{[0.043]}\end{array}$ & $\begin{array}{l}0.387^{* * *} \\
{[0.127]}\end{array}$ & $\begin{array}{l}0.207^{* * *} \\
{[0.043]}\end{array}$ & $\begin{array}{l}0.129 * * * \\
{[0.036]}\end{array}$ \\
\hline$E N P O s \_p c_{p}{ }^{*} e n v \_s t r i n{ }^{D}$ & $\begin{array}{l}-0.141^{* *} \\
{[0.070]}\end{array}$ & & $\begin{array}{l}-0.139^{* *} \\
{[0.062]}\end{array}$ & & $\begin{array}{l}-0.139^{* *} \\
{[0.062]}\end{array}$ & & $\begin{array}{l}-0.118^{* *} \\
{[0.059]}\end{array}$ & \\
\hline ENPOs_pc $c_{p}^{*} e n v \_s t r i n g$ & & $\begin{array}{l}-3.054^{* *} \\
{[1.320]}\end{array}$ & & $\begin{array}{l}-0.044^{* *} \\
{[0.022]}\end{array}$ & & $\begin{array}{l}-0.043^{*} \\
{[0.022]}\end{array}$ & & $\begin{array}{l}-0.044^{*} \\
{[0.024]}\end{array}$ \\
\hline$n o n-E N P O s_{-} p c_{p}$ & $\begin{array}{l}-0.104 \\
{[0.069]}\end{array}$ & $\begin{array}{l}-0.1 \\
{[0.068]}\end{array}$ & $\begin{array}{l}-0.099 \\
{[0.069]}\end{array}$ & $\begin{array}{l}-0.102 \\
{[0.068]}\end{array}$ & $\begin{array}{l}-0.099 \\
{[0.069]}\end{array}$ & $\begin{array}{l}-0.102 \\
{[0.068]}\end{array}$ & $\begin{array}{l}-0.1 \\
{[0.068]}\end{array}$ & $\begin{array}{l}-0.103 \\
{[0.067]}\end{array}$ \\
\hline mkt_prov & $\begin{array}{l}0.001 \\
{[0.001]}\end{array}$ & $\begin{array}{l}0.001 \\
{[0.001]}\end{array}$ & $\begin{array}{l}0.001 \\
{[0.001]}\end{array}$ & $\begin{array}{l}0.001 \\
{[0.001]}\end{array}$ & $\begin{array}{l}0.001 \\
{[0.001]}\end{array}$ & $\begin{array}{l}0.001 \\
{[0.001]}\end{array}$ & $\begin{array}{l}0.001 \\
{[0.001]}\end{array}$ & $\begin{array}{l}0.001 \\
{[0.001]}\end{array}$ \\
\hline satisfaction & $\begin{array}{l}0.064^{*} \\
{[0.038]}\end{array}$ & $\begin{array}{l}0.064^{*} \\
{[0.038]}\end{array}$ & $\begin{array}{l}0.048 \\
{[0.037]}\end{array}$ & $\begin{array}{l}0.049 \\
{[0.037]}\end{array}$ & $\begin{array}{l}0.048 \\
{[0.037]}\end{array}$ & $\begin{array}{l}0.049 \\
{[0.037]}\end{array}$ & $\begin{array}{l}0.048 \\
{[0.037]}\end{array}$ & $\begin{array}{l}0.049 \\
{[0.037]}\end{array}$ \\
\hline quality_cert & $\begin{array}{l}0.013 \\
{[0.036}\end{array}$ & $\begin{array}{l}0.015 \\
{[0.036]}\end{array}$ & $\begin{array}{l}0.02 \\
{[0.034]}\end{array}$ & $\begin{array}{l}0.02 \\
{[0.034]}\end{array}$ & $\begin{array}{l}0.02 \\
{[0.034]}\end{array}$ & $\begin{array}{l}0.02 \\
{[0.034]}\end{array}$ & $\begin{array}{l}0.02 \\
{[0.034]}\end{array}$ & $\begin{array}{l}0.02 \\
{[0.034]}\end{array}$ \\
\hline education & $\begin{array}{l}-0.03 \\
{[0.075]}\end{array}$ & $\begin{array}{l}-0.03 \\
{[0.075]}\end{array}$ & $\begin{array}{l}-0.045 \\
{[0.070]}\end{array}$ & $\begin{array}{l}-0.045 \\
{[0.071]}\end{array}$ & $\begin{array}{l}-0.045 \\
{[0.070]}\end{array}$ & $\begin{array}{l}-0.045 \\
{[0.071]}\end{array}$ & $\begin{array}{l}-0.046 \\
{[0.070]}\end{array}$ & $\begin{array}{l}-0.046 \\
{[0.071]}\end{array}$ \\
\hline rd_status & $\begin{array}{l}0.144^{* * *} \\
{[0.032]}\end{array}$ & $\begin{array}{l}0.144^{* * *} \\
{[0.032]}\end{array}$ & $\begin{array}{l}0.132^{* * * *} \\
{[0.029]}\end{array}$ & $\begin{array}{l}0.131^{* * *} \\
{[0.029]}\end{array}$ & $\begin{array}{l}0.132^{* * *} \\
{[0.029]}\end{array}$ & $\begin{array}{l}0.131^{* * *} \\
{[0.029]}\end{array}$ & $\begin{array}{l}0.131^{* * *} \\
{[0.029]}\end{array}$ & $\begin{array}{l}0.130^{* * * *} \\
{[0.029]}\end{array}$ \\
\hline patent $^{\text {For }}$ & $\begin{array}{l}0.149 \\
{[0.141]}\end{array}$ & $\begin{array}{l}0.152 \\
{[0.141]}\end{array}$ & $\begin{array}{l}0.12 \\
{[0.132]}\end{array}$ & $\begin{array}{l}0.121 \\
{[0.131]}\end{array}$ & $\begin{array}{l}0.12 \\
{[0.132]}\end{array}$ & $\begin{array}{l}0.121 \\
{[0.131]}\end{array}$ & $\begin{array}{l}0.121 \\
{[0.131]}\end{array}$ & $\begin{array}{l}0.121 \\
{[0.131]}\end{array}$ \\
\hline age & $\begin{array}{l}0.019 \\
{[0.027]}\end{array}$ & $\begin{array}{l}0.017 \\
{[0.027]}\end{array}$ & $\begin{array}{l}0.022 \\
{[0.027]}\end{array}$ & $\begin{array}{l}0.023 \\
{[0.027]}\end{array}$ & $\begin{array}{l}0.022 \\
{[0.027]}\end{array}$ & $\begin{array}{l}0.023 \\
{[0.027]}\end{array}$ & $\begin{array}{l}0.022 \\
{[0.027]}\end{array}$ & $\begin{array}{l}0.023 \\
{[0.027]}\end{array}$ \\
\hline size & $\begin{array}{l}-0.008 \\
{[0.025]}\end{array}$ & $\begin{array}{l}-0.008 \\
{[0.025]}\end{array}$ & $\begin{array}{l}-0.015 \\
{[0.024]}\end{array}$ & $\begin{array}{l}-0.013 \\
{[0.024]}\end{array}$ & $\begin{array}{l}-0.015 \\
{[0.024]}\end{array}$ & $\begin{array}{l}-0.012 \\
{[0.024]}\end{array}$ & $\begin{array}{l}-0.013 \\
{[0.024]}\end{array}$ & $\begin{array}{l}-0.012 \\
{[0.024]}\end{array}$ \\
\hline$k l$ & $\begin{array}{l}0.024 \\
{[0.018]}\end{array}$ & $\begin{array}{l}0.023 \\
{[0.018]}\end{array}$ & $\begin{array}{l}0.017 \\
{[0.015]}\end{array}$ & $\begin{array}{l}0.017 \\
{[0.015]}\end{array}$ & $\begin{array}{l}0.017 \\
{[0.015]}\end{array}$ & $\begin{array}{l}0.017 \\
{[0.015]}\end{array}$ & $\begin{array}{l}0.017 \\
{[0.015]}\end{array}$ & $\begin{array}{l}0.017 \\
{[0.015]}\end{array}$ \\
\hline waste $_{p}^{\text {sorted }}$ & $\begin{array}{l}0.005^{*} \\
{[0.002]}\end{array}$ & $\begin{array}{l}0.005^{*} \\
{[0.002]}\end{array}$ & $\begin{array}{l}0.004^{*} \\
{[0.002]}\end{array}$ & $\begin{array}{l}0.004^{*} \\
{[0.002]}\end{array}$ & $\begin{array}{l}0.004^{*} \\
{[0.002]}\end{array}$ & $\begin{array}{l}0.004^{*} \\
{[0.002]}\end{array}$ & $\begin{array}{l}0.004^{*} \\
{[0.002]}\end{array}$ & $\begin{array}{l}0.004^{*} \\
{[0.002]}\end{array}$ \\
\hline$v a \_p c_{p}$ & $\begin{array}{l}-0.125^{*} \\
{[0.072]}\end{array}$ & $\begin{array}{l}-0.112 \\
{[0.073]}\end{array}$ & $\begin{array}{l}-0.093 \\
{[0.079]}\end{array}$ & $\begin{array}{l}-0.102 \\
{[0.076]}\end{array}$ & $\begin{array}{l}-0.093 \\
{[0.079]}\end{array}$ & $\begin{array}{l}-0.103 \\
{[0.076]}\end{array}$ & $\begin{array}{l}-0.096 \\
{[0.078]}\end{array}$ & $\begin{array}{l}-0.104 \\
{[0.074]}\end{array}$ \\
\hline$e m p \_s h_{p}$ & $\begin{array}{l}-0.376 \\
{[0.577]}\end{array}$ & $\begin{array}{l}-0.381 \\
{[0.584]}\end{array}$ & $\begin{array}{l}-0.559 \\
{[0.516]}\end{array}$ & $\begin{array}{l}-0.545 \\
{[0.506]}\end{array}$ & $\begin{array}{l}-0.559 \\
{[0.516]}\end{array}$ & $\begin{array}{l}-0.546 \\
{[0.506]}\end{array}$ & $\begin{array}{l}-0.574 \\
{[0.510]}\end{array}$ & $\begin{array}{l}-0.555 \\
{[0.503]}\end{array}$ \\
\hline Observations & 905 & 905 & 986 & 986 & 986 & 986 & 986 & 986 \\
\hline Pseudo $\mathrm{R}^{2}$ & 0.079 & 0.08 & 0.072 & 0.072 & 0.072 & 0.071 & 0.071 & 0.071 \\
\hline
\end{tabular}

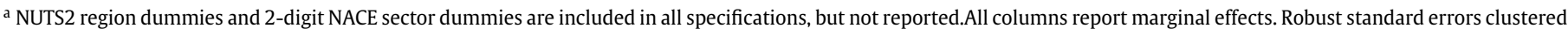
by NUTS3 regions are in brackets. $P$-value difference reports the statistical significance of the difference in the coefficient between equations.

${ }^{*} p<10 \%$; ${ }^{* *} p<5 \%$ level; ${ }^{* * *} p<1 \%$.

Some policy implications emerge from our study. While regulations preserve their prominent role for the environment protection, their enforcement can face some difficulties. To promote environmental protection, the involvement of specific types of societal stakeholders turns out to be critical. Whether local ENPOs can push local firms to adapt new environmental standards and ease innovation, or whether they promote firms' competitiveness, their action, like market-based environmental policies, has the advantage to provide greater flexibility to internalize pollution costs. The normative pressure local ENPOs exert may then be more effective than the coercive pressure of command-and-control regulatory policies, which fail to offer such flexibility. At the same time, local ENPOs exert a more capillary action than top-down market-based environmental policies, which may offer limited social rewards. The findings of our study bear also relevant implications for a number of European countries, where, like in Italy, family firms are the most common organizational form of economic activities. In these contexts, the positive pressure of ENPOs on GIS engagement by family business may turn into sizeable environmental benefits for society. Furthermore, our analysis suggest that the efforts of policy-maker should be directed to involve these societal actors in the implementation of, for example, environmental education programs aimed at the creation of an environmental ethic and at the promotion of ecologically oriented changes in values and behaviors.

Our study presents a number of limitations, which may inspire future research. First, our data enable us to investigate the influence of ENPOs on the likelihood of firms GIS. Yet, we lack a precise measure of the amounts of green investments to investigate the ENPOs influence on the intensity of firms' environmental investments. Future studies may explore this aspect. Second, we lack information about the nature of environmental investments (e.g., whether they trigger the introduction of sustainable products or production processes). The availability of such data would help understand the response of firms to ENPOs pressure by disclosing the existence of heterogeneous effects across different types of investments. In particular, investments aiming at sustainable production processes could be considered of greater interest for the local communities, and family firms could favor them over investments more oriented toward product sustainability. At the same time, ENPOs pressure may be more compelling towards the adoption of production processes (e.g. energy-saving processes), which delivers beneficial effects that external actors, such as noncoercive societal stakeholders, cannot immediately observe and assess. 


\section{Appendix A.}

Table A1

Correlation matrix and descriptive statistics (obs. 2275).

\begin{tabular}{|c|c|c|c|c|c|c|c|c|c|c|c|c|c|c|c|c|c|}
\hline & & 1 & 2 & 3 & 4 & 5 & 6 & 7 & 8 & 9 & 10 & 11 & 12 & 13 & 14 & 15 & 16 \\
\hline 1 & Green $^{I n v}$ & 1 & & & & & & & & & & & & & & & \\
\hline 2 & $E N P O s_{s} p c_{p}$ & $0.0427^{b}$ & 1 & & & & & & & & & & & & & & \\
\hline 3 & non - ENPOs_p $c_{p}$ & 0.0239 & $0.6692^{a}$ & 1 & & & & & & & & & & & & & \\
\hline 4 & mkt_prov & 0.0105 & 0.0052 & 0.01 & 1 & & & & & & & & & & & & \\
\hline 5 & satisfaction & $0.0890^{a}$ & -0.0198 & $-0.0407^{c}$ & $-0.0396^{c}$ & 1 & & & & & & & & & & & \\
\hline 6 & quality_cert & $0.1310^{a}$ & -0.0238 & $-0.0728^{a}$ & $-0.1042^{a}$ & $0.4075^{a}$ & 1 & & & & & & & & & & \\
\hline 7 & education & 0.0097 & $-0.0815^{a}$ & $-0.0471^{b}$ & $-0.0605^{a}$ & $0.0518^{b}$ & $0.1425^{a}$ & 1 & & & & & & & & & \\
\hline 8 & rd_status & $0.1077^{a}$ & $0.0641^{a}$ & $0.0593^{a}$ & $-0.1449^{a}$ & $0.0921^{a}$ & $0.1387^{a}$ & $0.1190^{a}$ & 1 & & & & & & & & \\
\hline 9 & group & $0.0675^{a}$ & -0.0043 & -0.011 & $-0.1012^{a}$ & $0.0422^{b}$ & $0.1728^{a}$ & $0.1626^{a}$ & $0.1801^{a}$ & 1 & & & & & & & \\
\hline 10 & patent $^{\text {For }}$ & $0.0471^{b}$ & $0.0602^{a}$ & $0.0546^{a}$ & $-0.052^{b}$ & $0.0557^{a}$ & 0.0131 & 0.0298 & $0.0741^{a}$ & $0.0739^{a}$ & 1 & & & & & & \\
\hline 11 & age & 0.0155 & $0.0405^{c}$ & 0.0258 & -0.0114 & 0.0138 & 0.0217 & $-0.0680^{a}$ & $0.047^{b}$ & $-0.0677^{a}$ & $0.0493^{b}$ & 1 & & & & & \\
\hline 12 & size & $0.1157^{a}$ & $0.038^{c}$ & 0.0368 & $-0.1976^{a}$ & $0.1193^{a}$ & $0.2480^{a}$ & $0.0364^{c}$ & $0.2701^{a}$ & $0.4331^{a}$ & $0.1310^{a}$ & $0.1085^{a}$ & 1 & & & & \\
\hline 13 & $k l$ & $0.1009^{a}$ & $-0.0417^{b}$ & $-0.0821^{a}$ & $-0.0406^{c}$ & $0.0730^{a}$ & $0.2070^{a}$ & $0.0349^{c}$ & 0.0108 & $0.1095^{a}$ & 0.0069 & $0.0685^{a}$ & $0.0850^{a}$ & 1 & & & \\
\hline 14 & waste $e_{p}^{\text {sorted }}$ & $-0.049^{b}$ & $0.1318^{a}$ & 0.0122 & 0.0238 & 0.001 & $-0.0774^{a}$ & $-0.0996^{a}$ & $0.0971^{a}$ & 0.024 & $0.0399^{c}$ & $0.1493^{a}$ & 0.009 & $-0.1230^{a}$ & 1 & & \\
\hline 15 & $v a \_p c_{p}$ & $-0.0570^{a}$ & $0.1860^{a}$ & $0.2116^{a}$ & 0.0268 & -0.0289 & $-0.0896^{a}$ & -0.002 & $0.1578^{a}$ & $0.0448^{b}$ & 0.0104 & $0.1330^{a}$ & 0.0338 & $-0.1865^{a}$ & $0.6349^{a}$ & 1 & \\
\hline \multirow[t]{5}{*}{16} & $e m p \_s h_{p}$ & $-0.0483^{b}$ & $0.3713^{a}$ & $0.3610^{a}$ & 0.0318 & -0.0222 & $-0.1036^{a}$ & $-0.1060^{a}$ & $0.1465^{a}$ & 0.0278 & $0.0412^{b}$ & $0.1222^{a}$ & 0.0208 & $-0.1646^{a}$ & $0.7098^{a}$ & $0.7368^{a}$ & 1 \\
\hline & Mean & 0.519 & -9.988 & -5.515 & 11.077 & 0.722 & 0.551 & 0.433 & 0.490 & 0.282 & 0.021 & 3.195 & 3.918 & 3.387 & 20.206 & 9.875 & 0.467 \\
\hline & $\mathrm{Sd}$ & 0.500 & 0.501 & 0.354 & 23.991 & 0.448 & 0.498 & 0.259 & 0.500 & 0.450 & 0.142 & 0.614 & 0.962 & 1.107 & 12.375 & 0.279 & 0.056 \\
\hline & Min & 0 & -12.597 & -6.497 & 0 & 0 & 0 & 0 & 0 & 0 & 0 & 0.693 & 2.079 & -4.360 & 0 & 8.910 & 0.287 \\
\hline & $\operatorname{Max}$ & 1 & -8.546 & -4.639 & 100 & 1 & 1 & 1 & 1 & 1 & 1 & 5.242 & 8.866 & 6.283 & 44.6 & 10.984 & 0.560 \\
\hline
\end{tabular}

${ }^{a} p<1 \%{ }^{b} p<5 \%$ level; ${ }^{c} p<10 \%$. 


\section{References}

Aden, J., Kyu-hong, A., Rock, M.T., 1999. What is driving the pollution abatement expenditure behavior of manufacturing plants in Korea? World Dev. 27, 1203-1214.

Antonietti, R., Marzucchi, A., 2014. Green tangible investment strategies and export performance: a firm-level investigation. Ecol. Econ. 108, 150-161.

Appolloni, A., Sun, H., Jia, F., Li, X., 2014. Green procurement in the private sector: a state of the art review between 1996 and 2013. J. Clean. Prod. 85, 122-133.

Argenti, P.A., 2004. Collaborating with activists: how starbucks works with NGOs. Calif. Manage. Rev. 47, 91-116.

Becker, R.A., 2003. Pollution abatement expenditure by U.S. manufacturing plants: do community characteristics matter? B.E. J. Econ. Anal. Policy 3, 1-23.

Bernauer, T., Böhmelt, T., Koubi, V., 2013. Is there a democracy-civil society paradox in global environmental governance? Glob. Environ. Polit. 13, 88-107.

Berrone, P., Cruz, C., Gomez-Mejia, L.R., Larraza-Kintana, M., 2010. Socioemotional wealth and corporate responses to institutional pressures: do family-controlled firms pollute less? Adm. Sci. Q. 55, 82-113.

Binder, M., Blankenberg, A.-K., 2016. Environmental concerns, volunteering and subjective well-being: antecedents and outcomes of environmental activism in Germany. Ecol. Econ. 124, 1-16.

Brunel, C., Levinson, A., 2013, Aug. Measuring Environmental Regulatory Stringency. OECD Trade and Environment Working Papers 2013/5. OECD Publishing.,

Cainelli, G., De Marchi, V., Grandinetti, R., 2015. Does the development of environmental innovation require different resources? Evidence from Spanish manufacturing firms. J. Clean. Prod. 94, 211-220.

Cartocci, R., 2007. Mappe Del Tesoro: Atlante Del Capitale Sociale in Italia. Il Mulino, Bologna.

Cennamo, C., Berrone, P., Gomez-Mejia, L.R., 2009. Does stakeholder management have a dark side? J. Bus. Ethics 89, 491-507.

Chrisman, J.J., Chua, J.H., Pearson, A.W., Barnett, T., 2012. Family involvement, family influence, and family-centered non-economic goals in small firms. Entrep. Theory Pract. 36, 267-293.

Clarkson, M.E., 1995. A stakeholder framework for analyzing and evaluating corporate social performance. Acad. Manag. Rev. 20, 92-117.

Cole, M.A., Elliott, R.J., Strobl, E., 2008. The environmental performance of firms: the role of foreign ownership, training, and experience. Ecol. Econ. 65, 538-546.

Commission, E., 2009. Final Report of the Expert Group. Overview of Family-Business-Relevant Issues: Research, Networks, Policy Measures and Existing Studies. (Novembre 2009).

Corbetta, G., Montemerlo, D., 1999. Ownership, governance, and management issues in small and medium-size family businesses: a comparison of Italy and the United States. Fam. Bus. Rev. 12, 361-374.

Cribb, R., 1990. The politics of pollution control in Indonesia. Asian Survey 30, $1123-1135$

De Marchi, V., 2012. Environmental innovation and R\&D cooperation: empirical evidence from Spanish manufacturing firms. Res. Policy 41, 614-623.

Deephouse, D.L., Carter, S.M., 2005. An examination of differences between organizational legitimacy and organizational reputation. J. Manag. Stud. 42, 329-360.

Doh, J.P., Guay, T.R., 2004. Globalization and Corporate Social Responsibility: How Non-governmental Organizations Influence Labor and Environmental Codes of Conduct. Management and International Review. Springer., pp. 7-29.

Doh, J.P., Guay, T.R., 2006. Corporate social responsibility, public policy, and NGO activism in europe and the United States: an institutional-stakeholder perspective. J. Manag. Stud. 43, 47-73.

Dyer, W.G., Whetten, D.A., 2006. Family firms and social responsibility: preliminary evidence from the s\&p 500. Entrep. Theory Pract. 30, 785-802.

Eesley, C., Lenox, M.J., 2006. Firm responses to secondary stakeholder action. Strateg. Manag. J. 27, 765-781.

Epstein, M.J., Schnietz, K.E., 2002. Measuring the cost of environmental and labor protests to globalization: an event study of the failed 1999 Seattle WTO talks. Int. Trade J. 16, 120-160.

Etzion, D., 2007. Research on organizations and the natural environment, 1992-present: A review. J. Manag. 33, 637-664.

Fredriksson, P.G., Neumayer, E., Damania, R., Gates, S., 2005. Environmentalism, democracy, and pollution control. J. Environ. Econ. Manag. 49, 343-365.

Freeman, R.E., 2004. The stakeholder approach revisited. Zeitschrift fü,r Wirtschafts-und Unternehmensethik 5, 228.

Gersick, K.E., Davis, J.A., Hampton, M.M., Lansberg, I., 1997. Empresas Familiares: Generación a Generación. McGraw-Hill México.

Gómez-Mejía, L.R., Haynes, K.T., Núñez-Nickel, M., Jacobson, K.J., Moyano-Fuentes, J., 2007. Socioemotional wealth and business risks in family-controlled firms: evidence from Spanish olive oil mills. Adm. Sci. Q. 52, 106-137.

Gomez-Mejia, L.R., Larraza-Kintana, M., Makri, M., 2003. The determinants of executive compensation in family-controlled public corporations. Acad. Manag. J. 46, 226-237.

Graafland, J.J., 2002. Sourcing ethics in the textile sector: the case of c\&a. Bus. Ethics: Eur. Rev. 11, 282-294.

Guay, T., Doh, J.P., Sinclair, G., 2004. Non-governmental organizations, shareholder activism, and socially responsible investments: ethical, strategic, and governance implications. J. Bus. Ethics 52, 125-139.
Guiso, L., Sapienza, P., Zingales, L., 2010. Civic Capital as the Missing Link. NBER Working Papers 15845. National Bureau of Economic Research, Inc.,

Habbershon, T.G., Pistrui, J., 2002. Enterprising families domain: family-influenced ownership groups in pursuit of transgenerational wealth. Fam. Bus. Rev. 15, 223-237.

Hamelin, A., 2013. Influence of family ownership on small business growth. Evidence from french smes. Small Bus. Econ. 41, 563-579.

Heckman, J.J., 1979. Sample selection bias as a specification error. Econometrica 47 153-161.

Henriques, I., Sadorsky, P., 1996. The determinants of an environmentally responsive firm: an empirical approach. J. Environ. Econ. Manag. 30, 381-395.

Horbach, J., 2008. Determinants of environmental innovation-new evidence from german panel data sources. Res. Policy 37, 163-173.

Horbach, J., Rammer, C., Rennings, K., 2012. Determinants of eco-innovations by type of environmental impact - the role of regulatory push/pull, technology push and market pull. Ecol. Econ. 78, 112-122.

Jones, T.M., Wicks, A.C., 1999. Convergent stakeholder theory. Acad. Manag. Rev. 24 206-221.

Kammerer, D., 2009. The effects of customer benefit and regulation on environmental product innovation: empirical evidence from appliance manufacturers in Germany. Ecol. Econ. 68, 2285-2295.

Laplume, A.O., Sonpar, K., Litz, R.A., 2008. Stakeholder theory: reviewing a theory that moves us. J. Manag. 34 (6), 1152-1189.

Madsen, P.M., 2009. Does corporate investment drive a "race to the bottom" in environmental protection? A reexamination of the effect of environmental regulation on investment. Acad. Manage. J. 52, 1297-1318.

Mazzanti, M., Montini, A., Nicolli, F., 2011. Embedding landfill diversion in economic geographical and policy settings. Appl. Econ. 43, 3299-3311.

Mazzanti, M., Zoboli, R., 2009. Embedding environmental innovation in local production systems: SME strategies, networking and industrial relations: evidence on innovation drivers in industrial districts. Int. Rev. Appl. Econ. 23, 169-195.

Miller, D., Breton-Miller, L., Lester, R.H., et al. 2011. Family and lone founder ownership and strategic behaviour: social context, identity, and institutional logics. J. Manag. Stud. 48, 1-25.

Mitchell, R.K., Agle, B.R., Wood, D.J., 1997. Toward a theory of stakeholder identification and salience: defining the principle of who and what really counts. Acad. Manag. Rev. 22, 853-886.

Moulton, B.R., 1990. An illustration of a pitfall in estimating the effects of aggregate variables on micro unit. Rev. Econ. Stat. 72 (2), 334-338.

Murillo-Luna, J.L., Garcés-Ayerbe, C., Rivera-Torres, P., 2008. Why do patterns of environmental response differ? A stakeholders' pressure approach. Strateg. Manag. J. 29, 1225-1240.

Nannicini, T., Stella, A., Tabellini, G., Troiano, U., 2013. Social capital and political accountability. Am. Econ. J. Econ. Pol. 5, 222-250.

Neumayer, E., Perkins, R., 2004, May. What explains the uneven take-up of ISO 14001 at the global level? A panel-data analysis. Environ. Plan. A 36, 823-839.

Ouyang, W., Guo, B., Cai, G., Li, Q., Han, S., Liu, B., Liu, X., 2015. The washing effect of precipitation on particulate matter and the pollution dynamics of rainwater in downtown beijing. Sci. Total. Environ. 505, 306-314.

Porta, R., Lopez-de Silanes, F., Shleifer, A., 1999. Corporate ownership around the world. J. Financ. 54, 471-517.

Porter, M.E., 1991. America's Green Strategy. Sci. Am. 264, 168.

Porter, M.E., van der Linde, C., 1995. Toward a new conception of the environmentcompetitiveness relationship. J. Econ. Perspect. 9, 97-118.

Rehfeld, K.M., Rennings, K., Ziegler, A., 2007. Integrated product policy and environmental product innovations: an empirical analysis. Ecol. Econ. 61, 91-100.

Schulze, W.S., Lubatkin, M.H., Dino, R.N., Buchholtz, A.K., 2001. Agency relationships in family firms: theory and evidence. Organ. Sci. 12, 99-116.

Sharma, S., Henriques, I., 2005. Stakeholder influences on sustainability practices in the Canadian forest products industry. Strateg. Manag. J. 26, 159-180.

Stafford, K., Duncan, K.A., Dane, S., Winter, M., 1999. A research model of sustainable family businesses. Fam. Bus. Rev. 12, 197-208.

Stiglitz, J.E., Weiss, A., 1981. Credit rationing in markets with imperfect information. Am. Econ. Rev. 71, 393-410.

Thornton, P.H., Ocasio, W., 1999. Institutional logics and the historical contingency of power in organizations: executive succession in the higher education publishing industry, 1958-1990 1. Am. J. Sociol. 105, 801-843.

Triguero, A., Moreno-Mondejar, L., Davia, M.A., 2013. Drivers of different types of eco-innovation in European SMEs. Ecol. Econ. 92, 25-33.

Villalonga, B., Amit, R., 2006. How do family ownership, control and management affect firm value? J. Financ. Econ. 80, 385-417.

Westhead, P., Cowling, M., Howorth, C., 2001. The development of family companies: management and ownership imperatives. Fam. Bus. Rev. 14, 369-385.

Yoshikawa, T., Rasheed, A.A., 2010. Family control and ownership monitoring in family-controlled firms in Japan. J. Manag. Stud. 47, 274-295.

Zahra, S.A., 2010. Harvesting family firms' organizational social capital: a relational perspective. J. Manag. Stud. 47, 345-366.

Zellweger, T., Sieger, P., 2012. Entrepreneurial orientation in long-lived family firms. Small Bus. Econ. 38, 67-84

Zhu, Q., Geng, Y., Sarkis, J., 2016. Shifting Chinese organizational responses to evolving greening pressures. Ecol. Econ. 121, 65-74. 